\title{
Effect of Process Variables on Some System Parameters and Physical Properties of Millet-Soybean Fura Extrudates
}

\author{
K. B. Filli (Corresponding author) \\ Department of Food Science and Technology
}

Federal University of Technology Yola, PMB 2076 Yola, Adamawa State

$\&$

Nigeria and SIK-The Swedish Institute for Food and Biotechnology Gothenburg

Sweden

Tel: 234-805-948-4668, 234-806-816-1260,46-722-127-964Ｅ-mail: kbfilli@yahoo.com

I. Nkama

Department of Food Science and Technology

University of Maiduguri PMB 1069 Maiduguri, Borno State, Nigeria

V. A. Jideani

Department of Food Technology, Cape Peninsula University of Technology

Bellville 7535, Cape Town, South Africa

U. M. Abubakar

Department of Food Science and Technology

University of Maiduguri PMB 1069 Maiduguri, Borno State, Nigeria

Received: April 27, 2012 Accepted: May 15, $2014 \quad$ Published: December 1, 2015

doi:10.5296/jfs.v4i1.1727ＵRL: http://dx.doi.org/10.5296/jfs.v4i1.1727 


\section{Abstract}

A three-factor three level central composite rotatable (CCRD) was adopted to study the effect of feed composition (X1), feed moisture content (X2) and screw speed (X3) on average residence time (ART), mass flow rate (MFR), specific mechanical energy (SME), expansion ratio (ER) and bulk density (BD) during extrusion of pearl millet and soybean flour mixtures for fura production (a Nigerian traditional food). The results shows that linear and quadratic terms showed significant $(\mathrm{P}<0.05)$ effect on the ART. The regression model for the data indicates that the proposed model was adequate showing significant $(\mathrm{P}<0.05)$, possessing lack of fit and with satisfactory coefficients of $\mathrm{R} 2=0.83,0.87,0.79 .0 .92$ and 0.96 for specific mechanical energy, mass flow rate, average residence time, expansion ratio and bulk density respectively, suggesting a good fit. The CCRD was effective in optimizing the process condition for fura as influenced by feed composition, feed moisture and screw speed. The importance of process variables on system parameters and physical properties could be ranked in the following order: Feed Moisture (X2) $>$ Feed Composition (X1) $>$ Screw Speed (X3). Response variables predicted with model equations under optimum conditions were in general agreement with experimental data. The data obtained from the system parameters and physical properties could be used for control of product characteristics and possible projection for the commercial production of millet-soybean based foods like fura.

Keywords: Mille, Soybean, Extrusion, Fura, Feed moisture; Feed composition, Screw speed, System parameters 


\section{Introduction}

High temperature short time (HTST) extrusion cooking technology has limitless applications in processing of cereal based products. Extrusion cooking is a popular means of preparing snacks and ready to eat foods. It is a versatile and efficient method of converting raw materials into finished food products. Its advantages include energy efficient, lack of process effluents and versatility with respect to ingredient selection, and the shapes and textures of products that can be produced. Extrusion processing is used for processing of starch as well as proteinious material. Extrusion technology could be applied for fura processing for the purpose of improving its shelf life and value addition to the product by making it a convenient food item (Nkama and Filli, 2006; Filli and Nkama, 2007).

Fura is one of the indigenous foods produced from cereals in Nigeria and West Africa at large. It is a traditional thick dough ball snack produced principally from millet or sorghum which is very common in Nigeria. The mode of preparation varies only slightly among different communities in the region, but the basic ingredient remains the same (i.e. millet or sorghum). Depending on the community it is consumed with nono (local yoghurt produced from cow milk) or mashed in water before consumption in the form of porridge. The consumption and acceptability of fura has suffered some draw back because the method of processing has remained a home-based or artisanal activity that is carried out with rudimentary equipment and techniques, which is characterized by inconsistent product quality, poor hygiene, very short shelf life and unacceptable standards. The product processing methods lacks process specifications governing composition, ingredients, additives and shelf life. Fura has a limited storage life with a range of $3-4$ days at refrigeration storage $\left(5^{\circ} \mathrm{C}\right), 1-2$ days at room temperature $\left(25^{\circ} \mathrm{C}\right)$ and 18 hours at $35^{\circ} \mathrm{C}$ (Jideani et al., 2002). Being a single cereal based product it is limiting in the essential amino acid lysine. The inclusion of soybean in producing fura will improve both protein content and quality. Interest in soybean foods has increased with consumer awareness of its health benefits, especially with soybean related ingredients being utilized as one of the major sources of high-protein fortification (United Soybean Board, 2006; Yeu et al., 2008). The US Food and Drug Administration have approved the use of soybean protein health claims on food labels since 1999. Clinical trial has shown a high association between consumption of soybean protein and the reduced risk of coronary heart diseases (E. de Mesa, et al., 2009). They also reported that in addition to the cholesterol lowering effect of soybean protein, it has anticarcinogenic effects, and it deters obesity, diabetes, digestive tract irritation, and bone and kidney diseases.

Despite increased use of extrusion processing, extrusion is still a complicated multiple -input - multiple output process that has yet to be mastered. Small variations in processing conditions can affect processs variables as well as product quality depending on the extruder type, screw configuration, feed moisture, and temperature profile in the barrel session, screw speed, die configuration and feed rate (Qing-Bo Ding et al, 2005; Neelam et al., 2006). A simplied model affecting extrusion processing has been reported by (Brummer et al., 2002; Chessari and Sallahewa, 2001); this was modified by (Onyango 2005), which classified extrusion parameters into four classes, namely process parameters (screw speed, screw geometry, die geometry etc.), system parameters (mass flow rate, specific mechanical energy, 
torque etc.), feed properties (starch, protein, moisture, fat etc.) and product properties (physical, functional, nutritional, sensory etc). Among these four sets of parameters, process parameters have effects on the properties of extrudates by means of affecting extrusion system parameters (Liang Chen et al., 2008). As a result of the 'black box' characteristic of extruder and limitation of in-line detection, many researchers focus on the influence of process parameters on product properties, disregarding the role of system parameters (Pham and Del Rosario, 1984; Wang et al., 2001; Ding et al., 2006; Liang -Chen et al., 2008) therefore, few literatures related to extrusion system parameters alone are available without considering extrudate properties (Akdogan, 1996; Wang, 2005; Kang et al., 2007 a,b; Liang - Chen et al., 2008). To provide a better insight of the effect of extrusion process it is necessary to research the relationship between feed properties, process parameter and system parameters. The specific mechanical energy has been used by Meuser and Van Lengerich (1992) as a system parameter to model the extrudate properties. The effects of ingredient properties and processing conditions on final product quality are also reflected by their influence on process responses or extruder system parameters such as motor torque, die pressure, product temperature, and specific mechanical energy (Meng et al., 2010). As they are a result of different combinations of extrusion conditions such as feed moisture, screw speed, and barrel temperature, system parameters can be used to describe or compare extrusion process under different operating conditions (Moraru and Kokini, 2003). It has been shown that specific mechanical energy correlates well with extrudate properties such as expansion ratio, density and textural characteristics (Meauser and Van Lengerich, 1992; Ilo et al., 1996; Dogan and Karwe, 2003; Altan et al., 2008; Meng et al., 2010). Binoy et al. (1996) reported that a more severe screw resulted in increased mixing, residence time, and both shear and thermal energy inputs to materials in the filled sections created by the reverse screw elements and thereby increased starch conversion in the feed material. Shear activation energy is three orders of magnitude smaller than thermal activation energy (Wang et al., 1991; Gogoi et al., 1995). Binoy et al. (1996) observed decreasing specific mechanical energy with addition of fish solids to rice flour for each screw configuration used.

The objectives of this work was to study the effects of feed composition, feed moisture and screw speed on the system parameters; average residence time (ART), mass flow rate (MFR), specific mechanical energyy (SME), expansion ratio (ER) and bulk density (BD) during extrusion of pearl millet and soybean flour mixtures for fura production using response surface methodology (RSM).

\section{Materials and methods}

\subsection{Flour preparation from millet}

The process of flour preparation consists of dry cleaning of millet i.e. winnowing using an aspirator Vegvari Ferenc (OB125, Hungary). The kernels were thereafter dehulled after mild wetting of the grain using a rice dehuller (India) at the Jimeta Main Market, Yola, Nigeria. After dehulling, the grains were washed and then dried in a Chirana convection oven model (HS 201A, Czech Republic) at $50^{\circ} \mathrm{C}$ for 24 hours to $14 \%$ moisture content. The dried grain was milled using a Brabender roller mill (OHG DUISBURG model 279002, Germany) 
equipped with a $150 \mu \mathrm{m}$ screen.

\subsection{Flour preparation from soybean}

The soybean seeds were steeped in tap water at $28^{\circ} \mathrm{C}$ for a period of 24 hours in a plastic bowl. The kernels were thereafter dehulled using traditional pestle and mortar. After dehulling, the grains were washed and the hulls removed. The grains were thereafter dried in a Chirana convection oven model (HS 201A, Czech Republic) at $50^{\circ} \mathrm{C}$ for 24 hours to $14 \%$ moisture content and the mass was winnowed to remove the remaining lighter materials using an aspirator Vegvari Ferenc (OB125, Hungary). The dehulled soybean kernels were ground in a laboratory disc mill (Nigeria) to fine flour. The flour was sieved using a150 $\mathrm{mm}$ screen, and the underflow was used for further research work.

\subsection{Spice preparations}

Kimba (Negro pepper) and ginger were sorted and cleaned manually before drying in a Chirana convection oven model (HS 201A, Czech Republic) at $60^{\circ} \mathrm{C}$ for five hours. The seeds were then pounded using the traditional pestle and mortar. The mass was ground and sieved using a $150 \mu \mathrm{m}$ screen size.

\subsection{Blend preparations and moisture adjustment}

Millet flour $\left(\mathrm{M}_{\mathrm{F}}\right)$ and soybean flour $\left(\mathrm{S}_{\mathrm{F}}\right)$ were mixed at various weight ratios, and the total moisture contents of the blends adjusted to the desired values with a mixer as described by Zasypkin and Tung-Ching Lee, (1998). Weights of the components to be mixed were calculated using the following formula:

$$
\begin{gathered}
C_{S F}=\frac{\left[r_{S F} \times M \times(100-w)\right]}{\left[100 \times\left(100-w_{S F}\right)\right]} \\
C_{M F}=\frac{\left[r_{M F} \times M \times(100-w)\right]}{\left[100 \times\left(100-w_{M F}\right)\right]} \\
W_{X}=M-C_{S F}-C_{M F}
\end{gathered}
$$

$C_{S F}$ and $C_{M F}$ are the masses of soybean flours $\left(\mathrm{S}_{\mathrm{F}}\right)$ and millet flour $\left(\mathrm{M}_{\mathrm{F}}\right)$, respectively, $r_{S F}$ or $r_{M F}$ are respective percentages of either soybean flours $\left(\mathrm{S}_{\mathrm{F}}\right)$ or millet flour $\left(\mathrm{M}_{\mathrm{F}}\right)$ in the blend, d.b.; $\left(r_{S F}+r_{M F}=100 \%\right) ; M$ is the total mass of the blend; $w$, the moisture content of the final blend, percentage wet weight basis (w.w.b.); $W_{X}$ is the weight of water added; and $w_{S F}$ and $w_{M F}$ are the moisture contents of $\mathrm{S}_{\mathrm{F}}$ and $\mathrm{M}_{\mathrm{F}}$, respectively. The blends were mixed in a plastic bowl with the addition of the spices (Kimba \& Ginger) at $1 \%$ level based on traditional formula; and the whole packed in polyethylene bags which was kept in the refrigerator overnight to allow moisture equilibration. The samples were however brought to room temperature before extrusion process.

\subsection{Experimental design}

A three-factor central composite rotatable composite design [CCRD] (Box and Hunter, 1957) was adopted to study the effect of feed composition $\left(\mathrm{X}_{1}\right)$, feed moisture content $\left(\mathrm{X}_{2}\right)$ and 
screw speed $\left(\mathrm{X}_{3}\right)$ on average residence time (ART), mass flow rate (MFR), specific mechanical energy (SME), expansion ratio (ER) and bulk density during extrusion of pearl millet and soybean flour mixtures for fura production. The independent variables and their variation levels are shown in Table 1. The levels of each variables were established according to literature information and preliminary trials. The outline of the experimental layout with the coded and natural values are presented in Table 2. Homogeneous variances or homoscedasticity is a necessary pre-requisite for (linear) regression models. Therefore, a reduction in variability within the objective response (dependent variables) was by transforming the data to standardized scores $\left(z=\frac{x-\bar{x}}{s}\right.$ where $x=$ dependent variable of interest; $\bar{x}=$ mean of dependent variable of interest and $\mathrm{s}=$ standard deviation).

\subsection{Extrusion exercise}

Extrusion cooking was performed in a single screw extruder, model (Brabender Duisburg DCE-330, Germany) equipped with a variable speed D-C drive unit, and strain gauge type torque meter. The screw has a linearly tapered rod and 20 equidistantly positioned flights. The extruder was fed manually through a screw operated conical hopper at a speed of $30 \mathrm{rpm}$ which ensures the flights of the screw filled and avoiding accumulation of the material in the hopper. This type of feeding provides the close to maximal flow rate for the selected process parameters (constant temperature, constant die and screw geometry but with three variable screw speeds) and three designed feed composition and feed moisture contents. A round channel die with separate infolding heater was used. The die used was a cone shaped channel with 45 degrees entrance angle, a $3 \mathrm{~mm}$ diameter opening and $90 \mathrm{~mm}$ length. The screw was a 3:1 compression ratio. The inner barrel is provided with a grooved surface to ensure zero slip at the wall. The barrel is divided into two independent electrically heated zones that is (feed end and central zone). There is a third zone at the die barrel, electrically heated but not air cooled. The extruder barrel has a $20 \mathrm{~mm}$ diameter with length to diameter ratio (L:D) of 20:1. Desired barrel temperature was maintained by a circulating tap water controlled by inbuilt thermostat and a temperature control unit. The feed material was fed into a hopper mounted vertically above the end of the extruder which is equipped with a screw rotated at variable speed. The rotating hopper screw kept feed zone completely filled to achieve a 'choke fed' condition. Experimental samples were collected when steady state was achieved that is when the torque variation of \pm 0.28 joules $(\mathrm{Nm})$ or about $(0.5 \%)$ of full scale (Likmani et al.,1991). The extrusion process consisted of 15 individual runs and conducted randomly.

\subsection{Average residence time (ART)}

In any food processing operations it is important to control the processing time of the food. This was determined by dividing the barrel (tube) volume by the volumetric flow rate of extrudate, (Lewis, 1987). 
Average residence time $($ ART $)=\frac{\text { Volume of tube }}{\text { Volumetric flow rate }}=\frac{V\left(m^{3}\right)}{Q\left(\left(m^{3} s^{-1}\right)\right)}(\mathrm{s})(4)$

If the internal diameter of the tube is equal to $\mathrm{D}$ and the average velocity is $4 \mathrm{Q} / \pi \mathrm{D}^{2} \mathrm{~s}$, the appropriate expression of volumetric flow rate was obtained or derived from the above equation. The time was measured in seconds.

\subsection{Mass flow rate (MFR)}

The mass flow rate $\left(\mathrm{g} \mathrm{s}^{-1}\right)$ was evaluated by the method described by Zasypkin and Tung-Ching Lee (1998), which was calculated as the mass of material extruded per minute. Calculations were made from the data on product output $\left(\mathrm{Q}_{\mathrm{E}}\right)$ and the moisture content of the product extrudate ( $\mathrm{w} \% \mathrm{w} . \mathrm{b}$.), according to the following formula:

$$
M F R=Q_{E}\left[\frac{(100-w)}{(100-W)}\right] \mathrm{g} \mathrm{s}^{-1}
$$

Water contents of the samples and the product output, determined as mass of the final product was measured about 1 hour after extrusion. Water content was measured by drying the samples to a constant weight at $105^{\circ} \mathrm{C}$. The mass flow rate was calculated as the mass of product delivered per time.

\subsection{Specific mechanical energy (SME)}

The specific mechanical energy was determined as described by Binoy et al. (1996) from the torque on the drive motor at constant screw speed and mass flow rate. In the extruder, this energy was provided by a $4.1 \mathrm{Kw}$ electric motor, which is coupled to the screw. SME $(\mathrm{KJ} / \mathrm{Kg})$ was calculated using the following equation:

$$
S M E=\frac{\mathrm{n}(\text { actual }) \times \% \text { net torque } \times \mathrm{P}(\text { rated })}{\mathrm{n}(\text { rated }) \times 100 \times \mathrm{m}}(6)
$$

where $\mathrm{n}=$ screw speed $(\mathrm{rpm})$; net torque $=$ the measured torque less the lot frictional torque due to bearings and gear drive assembly; $\mathrm{P}=$ motor power $(\mathrm{KJ} / \mathrm{s})$; and $\mathrm{m}=$ feed rate $(\mathrm{Kg} / \mathrm{s})$.

\subsection{Expansion ratio (puff ratio)}

Expansion ratio can be of two indices, diametral and longitudinal as described by Sopade and Le Grys (1991). Diametral expansion is defined as the diameter of the extrudate whilst longitudinal expansion is defined as the length per unit dry weight. The diameter was determined after cooling of the extrudate, 10 samples were assessed for each extrudate and for each sample; diameters at three different positions were taken using vernier calipers and the result averaged. Expansion ratio expressed as the diameter of the extrudate to the diameter of the die.

\subsection{Bulk density of extrudates}

The bulk density of extrudates was calculated using the methods described by Qing-Bo et al. (2005) as follows: 


$$
\text { Density }=\frac{4 \times \AA}{\pi \times D \times D \times L}(7)
$$

where å is the mass of extrudate with length $\mathrm{L}$ and diameter D. The samples were randomly selected and replicated 10 times and the average value taken.

\subsection{Statistical analysis}

For each standardized scores, analysis of variance (ANOVA) was conducted to determine significant differences among the treatment combinations. Also, data were analyzed using multiple regression procedures (SPSS, 2008). Statistical significant difference between values was evaluated at $\mathrm{P}<0.05$ level with multiple comparison test using (SPSS, 2008) and correlation between parameters using Microsoft Excel 2002 (Microsoft Corporation, Sacramento, USA). A quadratic polynomial regression model was assumed for predicting individual responses (Gacula and Singh, 1984; Wanasundara and Shahidi, 1996). The model proposed for each response of $\mathrm{Y}$ was:

$$
Y=b_{0}+b_{1} X_{1}+b_{2} X_{2}+b_{3} X_{3}+b_{11} X_{1}^{2}+b_{22} X_{2}^{2}+b_{33} X_{3}^{2}+b_{12} X_{1} X_{2}+b_{13} X_{1} X_{3}+b_{23} X_{2} X_{3}
$$

where $\mathrm{Y}=$ the response $\mathrm{X}_{1}=$ Feed Composition, $\mathrm{X}_{2}=$ Feed Moisture, $\mathrm{X}_{3}=$ Screw Speed, $\mathrm{b}_{0}=$ intercepts, $b_{1}, b_{2}, b_{3}$ are linear, $b_{11}, b_{22}, b_{33}$ are quadratic and $b_{12}, b_{13}$ and $b_{23}$ are interaction regression coefficient terms. Coefficients of determination $\left(\mathrm{R}^{2}\right)$ were computed. The adequacy of the models was tested by separating the residual sum of squares into pure error and lack of fit. For each response, response surface plots were produced from the fitted quadratic equations, by holding the variable with the least effect on the response equal to a constant value, and changing the other two variables.

\section{Results and Discussion}

\subsection{Average residence time (ART)}

The mean result of ART of the extruded products is shown in Table 3. The ART reflect the mean time duration and the pattern of material to transit through the extruder barrel. It is a time distribution because of the transport mechanism through the barrel resulting in various degrees of spread instead of plug flow. It represents the time that the material is exposed to the heat, shear and other chemical reactions that occur in the extruder barrel (Pansawat, et al., 2008). Analysis of variance (table not shown) indicates that the linear and quadratic effects of the independent variables significantly $(\mathrm{P}<0.05)$ affected the ART. However, there was no significant effect observed by the interaction term on the ART. The regression coefficients for the second order polynomial equations showing the linear, quadratic and interaction terms are presented in Table 4. Feed composition, feed moisture as well as screw speed all had negative linear coefficient indicating a reduction in ART when extrusion variables were increased. Both feed composition and feed moisture resulted in significant $(\mathrm{P}<0.05)$ quadratic increases in ART. The model with adjusted $\mathrm{R}^{2}$ of 0.595 was significant $(\mathrm{P}<0.05)$ explaining about $60 \%$ of variability. However, the lack of fit was significant $(\mathrm{P}<0.05)$. The effect of the 
independent variables on ART is in the order of feed moisture $>$ feed composition $>$ screw speed. Figure 1 indicates the response surface for ART as affected by feed composition and feed moisture. From the figure the maximum estimated ART (31.64 s) was obtained with $10 \%$ soybean flour and $20 \%$ feed moisture. The least ART (19.12 s) was obtained with $27.5 \%$ soybean flour and $23.75 \%$ feed moisture. It is clear that increased screw speed resulted in decreased ART which is supported by the report of (Pansawatt et al., 2008). The effects of increased screw speed on ART reduction might be attributed to decreased degree of fill. It has been reported that material compositions play an important role in influencing process parameters. Decreasing feed moisture indicated increasing ART while increasing the level of soybean flour appears to marginally reduce the ART. Screw speed had marginal influence on the resident time, increasing screw speed as expected reduced the ART (result not shown). Lower screw speed resulted in a longer residence time of extrudates in the extruder (Van Zuilichem et al., 1988). Since extruder configuration was kept constant for this study the observed ART must be related to dough viscosity as influenced by feed composition, feed moisture and screw speed. If the physicochemical changes known to occur in food extrusion could be neglected, viscosity would be expected to be inversely related to both moisture and screw speed, viscosity would in turn be directly related to residence time and inversely related to mass flow rate. The studies on the average residence time (ART) of food in the extruder during extrusion is to understand the flow patterns and can enable one predict the performance of an extruder. The reason being that there are several reactions, such as gelatinization of starch, denaturation of protein, enzyme inactivation and maillard reactions are affected by the residence time in the extruder (Chuang and Yeh, 2004).

\subsection{Mass flow rate (MFR)}

The mean values of MFR of the extruded products are shown in Table 3. Linear, interaction and quadratic effects of the independent variables affected the MFR significantly $(\mathrm{P}<0.05)$. The response equation coefficient for MFR is presented in Table 4. The positive significant linear coefficients of feed moisture and screw speed indicated that their effect on MFR were increases. The negative quadratic coefficient of feed moisture suggests that the quadratic effect decreases MFR. There was a significant $(\mathrm{P}<0.05)$ interaction between feed composition and feed moisture resulting in increase in MRF. The proposed model with adjusted $R^{2}=0.755$, and no significant lack of fit was adequate in explaining the effects of the independent variables on MFR. The response surface plot of feed moisture and screw speed on MFR is shown in Figure 2. The maximum estimated value of MFR $\left(1.47 \mathrm{gs}^{-1}\right)$ was obtained using $26.25 \%$ soybean flour and 237.5 rpm screw speed; $26.25 \%$ soybean and 250 rpm screw speed; $27.5 \%$ soybeans and $250 \mathrm{rpm}$. The lowest value of MFR $\left(1.22 \mathrm{gs}^{-1}\right)$ was however observed for $20 \%$ soybean and $150 \mathrm{rpm} ; 25 \%$ soybean and $150 \mathrm{rpm}$. In cases of scaling-up and transferring processes to different extruder geometries, the residence time is a useful parameter for comparison since it is measured easily and is a result of mass flow patterns (Kumar et al., 2008).

\subsection{Specific mechanical energy (SME)}

The mean value of SME of the extruded products is shown in Table 3. Analysis of variance 
(table not shown) indicates that the linear and quadratic effects of the independent variables significantly $(\mathrm{P}<0.05)$ affected the SME. The response equation coefficient for SME is presented in Table 4 . The regression models for data were significant $(\mathrm{P}<0.05)$ with satisfactory coefficients of $\mathrm{R}^{2}=0.826$ for SME. The coefficients of variation $(\mathrm{CV})$ were less than $<10 \%$ (result not shown) suggesting the models could be reproducible (Montgomery, 1984). Examination of these parameters indicated that linear effect of screw speed and quadratic effects of feed composition and feed moisture had a significant $(\mathrm{P}<0.05)$ decrease on SME. However, the quadratic effect of screw speed indicated an increase in SME. Since extruder configuration was kept constant for this study the observed ART and MFR must be related to dough viscosity as influenced by feed composition, feed moisture and screw speed. If the physicochemical changes known to occur in food extrusion could be neglected, viscosity would be expected to be inversely related to both moisture and screw speed. Viscosity would in turn be directly related to residence time and inversely related to mass flow rate. The amount of mechanical energy delivered to the extruded material plays a role in starch conversion. It has been reported that starch gelatinization of extrudate increased with increasing specific mechanical energy during extrusion (Ilo et al., 1996) through the shear effects. Higher SME usually results in greater degree of starch gelatinization and extrudate expansion. Hence, increased SME is desired for expanding products. Feed moisture and feed composition strongly influenced the SME, as expected decreasing feed moisture resulted in increased SME. Choudhury and Gautan (2003) reported that increasing the amount of fish solids in the hydrolyzated fish muscle and rice blend resulted in lowering the SME input, reducing mixing and increasing the mean residence time. The power transmitted by the drive motor to the screws can be expressed as (Martelli, 1983):

$$
Z=f\left(\frac{Q^{2} \mu \hat{u} N n^{2}}{K}\right)(9)
$$

where $\mathrm{Q}=$ output $\left(\mathrm{m}^{3} / \mathrm{s}\right) ; \mu=$ melt viscosity in the filled channels $\left(\mathrm{Nsm}^{-2}\right) ; \hat{\mathrm{u}}=$ average viscosity in the filled channels $\left(\mathrm{Nsm}^{-2}\right) ; \mathrm{N}=$ number of filled flights; $n=$ screw speed $(1 / \mathrm{s})$; and $\mathrm{K}$ conductivity of the die $\left(\mathrm{m}^{2}\right)$. The response surface plot (Figure 3 ) showed that the specific mechanical energy SME was decreasing as screw speed increased while SME marginally decreased as feed moisture increased. Contrary to our study, Altan et al. (2009) reported that, SME decreased with increasing temperature and decreasing screw speed during the extrusion of barley-tomato pomace blends. The variation of their report with this study might be attributed to the differences in the materials used. In addition, temperature was kept constant for our study; lubricating effect could possibly have contributed due to oil in soybean. This might have reduced the viscosity and consequently the shear effect. Baik et al. (2004) reported that increasing the screw speed causes increase in SME input attributed to the increase in shear rate with increased screw speed. Janes, (1993) reported that in general, adding about $0.5 \%$ vegetable oil to a cereal based mixture significantly decreases the SME input in the low moisture extrusion cooking, if the other extrusion variables are kept constant. Altan et al. (2009) reported that SME was depended on the type of raw material used and screw configuration. Decrease in specific energy with increasing moisture content for this study was in agreement with the findings of other workers obtained during extrusion 
processing of starch based materials (Antila, et al., 1983; Meuser \& van Lengerich, 1984a,b; Meuser et al., 1985, 1987; Senouci \& Smith, 1986; Mange \& Boissonant, 1987; Della Valle et al., 1989). Combined dual effects of water and oil from the soybean flour decreased the viscosity which lowers the shear effect leading to drop in the SME. Feed moisture is a key factor in determining flow properties of food dough during extrusion cooking. Increased feed moisture decreases the viscosity of food dough (as indicated by lowered die pressure) and reduces the rotating friction of the screws which is translated into lowered torque (Govindasamy et al., 1997). Lubricating effects of water lowers the SME input. Viscosity of the starch mass and its ability to dissipate mechanical energy decreases when the water content is high. The specific mechanical energy reported by Qing-Bo et al. (2005) was found to be dependent on feed moisture, feed rate, screw speed and temperature; and among them feed moisture was found to be the most significant factor. Sandra et al. (1993) reported that the high energy input and high shear may induce a high degree of denaturation and breakdown of secondary structure of proteins. However, the process appears to favour protein juxtaposition at the molecular level allowing protein interactions to stabilize the three dimensional structure to include antiparallel ß-sheet structures.

\subsection{Expansion ratio}

The mean values ER of the extruded products are shown in Table 3. Analysis of variance (table not shown) indicates that only the linear effects of the independent variables significantly $(\mathrm{P}<0.05)$ affected the expansion ratio. The response equation coefficient for ER is presented in Table 4. The models showed good fit with adjusted $\mathrm{R}^{2}=0.0 .83$ for ER. This suggests a very good fit to the experimental data and the model could be used to describe the process. The negative significant $(\mathrm{P}<0.05)$ linear coefficients of feed composition and feed moisture indicated that their effect on ER were a decrease. Moisture plays a key role in the mechanism responsible for expansion. This is clearly shown in the 3D plot figure 4 . From the plot it shows that increasing feed moisture resulted in decreased ER. Increasing the amount of soybean flour indicated decrease in the ER. Considering the elastic properties of the amylopectin network as being responsible for diametral expansion is helpful in explaining such role of moisture. This is a commonly observed phenomenon in many extruded foods, which can be attributed to the fact that the amount of expansion in a food material depends on pressure differential between the die and the atmosphere. Food with lower moisture content tend to be more viscous than those having higher moisture content, therefore, the pressure differential is smaller for higher moisture foods leading to a less expanded product. However increasing screw speed resulted in increase in ER (result not shown). Increasing screw speed tends to increase the shearing effect, this causes protein molecules to be stretched farther apart, weakening bonds and resulting in a puffer product. Harmann and Harper (1973) postulated two factors in governing expansion: (a) dough viscosity, and (b) elastic force (die swell in the extrudate. The elastic forces will be dominant at low moisture and temperature. The bubble growth, which is driven by the pressure difference between the interior of the growing bubble and atmospheric pressure resisted primarily by the viscosity of the bubble wall, dominate the expansion at high moisture content high temperature (Panmanabhan \& Bhattacharyya, 1989). A viscoelastic melt in a food extruder expands due to flashing of 
moisture at the die exit. The expansion process can be described as nucleation in the die, extrudate swelling immediately beyond the die, followed by bubble growth and collapse (Kokini et al., 1991). Increased water content in the melt would soften the amylopectin molecular structure and reduce its elastic characteristics to decrease diametral expansion (Avarez-Martinez et al., 1988). In addition increased level of soybean flour marginally decreased expansion ratio which is expected because of the high fat in the soybean flour. Feed moisture has been identified as the main factor affecting extrudate expansion and density (Faubion \& Hosney, 1982; Harper \& Tribelhorn, 1992; Gujral et al., 2001). Extrudates can expand in both the cross-sectional (diametrical) direction and the longitudinal direction (Launary and Lisch, 1983). A porous, expanded, sponge-like structure is formed inside extrudates as a result of many tiny steam bubbles created by the rapid release of pressure after exiting the die (Conway, 1971). Increased feed moisture during extrusion would provoke change in the amylopectin molecular structure of the material reducing the melt elasticity thus decreasing the expansion and increasing the density of extrudate (Qing-Bo et al., 2005). A puffer extrudate resulted by decreasing the lipid content in the feed mix (Bhatacharya \& Hamma, 1988). Singh et al. (2007) reported decrease in ER with increase in feed moisture of rice-pea grits extrudates. Extruded snacks possess the typical texture of puffed, light and crispy. Some physical properties of extruded snack were reported including bulk density of 48-64 g/L, 50-160 g/L (Moore, 1994) and 59 10g/L (Boonyasirikool et al., 1996) and expansion ratio of 3.06 - 3.83 (Mohamed, 1990) and 4.03 (Boonyasirikool et al., 1996). Seker, (2005) reported that increasing screw speed improved sectional expansion and reduced bulk density of extrudate during extrusion of soybean protein and corn starch. He further reported that mixtures of soybean protein isolate/modified starch had higher sectional expansion indices than those of native starch/soybean protein isolate, indicating that feed materials (in addition to phase transition) may contribute to the reduced expansion of extrudate containing soybean protein. Modified starch/soybean protein isolate mixtures had lower bulk densities than native starch/soybean protein isolate mixtures and it is suggested that bulk densities of extrudate containing high levels of soybean protein can be reduced by inclusion of cross linked starch in the extrusion mix. Chaiyakul et al. (2009) reported that expansion was greatest for low protein, low moisture and high temperatures during the extrusion of high protein glutinous rice based snack. These relationships have been reported elsewhere for corn and wheat based snacks (Bhattacharya and Hanna, 1987; Chinnaswamy and Hanna, 1990; Faubion and Hosney, 1982; Ilo et al., 1999). Filli and Nkama, (2007) reported that pearl millet: cowpea fura (80:20) had the highest puff ratio of 4.71 while the pearl millet: groundnut (70:30) fura had the least puff ratio, 2.90.

\subsection{Bulk density}

The mean values of BD of the extruded products are shown in Table 3. Density measures the total volume of the extrudates, indicating the extent of expansion. The experimental value of $\mathrm{BD}$ varied from 0.12 to $0.47 \mathrm{gcm}^{-3}$. Analysis of variance (table not shown) indicates that the linear and quadratic effects of the independent variables significantly $(\mathrm{P}<0.05)$ affected the bulk density. The response equation coefficient for BD is presented in Table 4. The models showed good fit with adjusted $\mathrm{R}^{2}=0.93$ for $\mathrm{BD}$. This suggests a very good fit to the 
experimental data and the model could be used to describe the process. The positive significant $(\mathrm{P}<0.05)$ linear coefficients of feed composition, feed moisture and screw speed indicated that their effect on BD were an increase. However, the negative significant $(\mathrm{P}<0.05)$ coefficients linear effect of screw speed and quadratic interaction of feed composition resulted in a decrease in BD. The 3D surface plots BD is shown in Figures 5 and 6. Feed composition and screw speed appears to significantly influence the bulk density (BD). Increasing the level of soybean flour resulted in increased BD, while the BD decreases as a result of increased screw speed marginally, Figure 5. Feed moisture influenced BD significantly Figure 6. Increasing feed moisture resulted in increased BD. Hagenimana et al. (2006) reported that the BD increased with increase in moisture content during the extrusion of rice flour. Traditionally; extrudate expansion has been expressed in terms of radial enlargement and decrease in density which have been correlated with changes in melt moisture and temperature. Bulk density is a measure of how much expansion has occurred as a result of extrusion. The heat developed during extrusion can increase the temperature of the moisture above the boiling point so that when the extrudate exits from the die, a part of the moisture would quickly flash-off as steam and result in an expanded structure with large alveoli and low bulk density. On the other hand, if not enough heat is generated to flash-off enough of the moisture (either through low process temperature or high feed moisture), less expansion occurs resulting in a high bulk density product with collapsed cells which usually disintegrates on cooling. High bulk density product is an indication of more uniform and continuous protein matrix and therefore, the extrudate is dense with parallel layers, no air pockets and is not spongy upon hydration (Taranto et al., 1978). Qing-Bo et al. (2005); Meng et al. (2010) reported extrudate density to be most depended on feed moisture, increased feed moisture lead to sharp increase of extrudate density. Screw speed was observed to have slight impact on the density of extrudate. High bulk density product is an indication of more uniform and continuous protein matrix and therefore, the extrudate is dense with parallel layers, no air pockets and is not spongy upon hydration (Taranto et al., 1978).

\subsection{Extrudate photographic responses}

The effects of extrusion variables (feed composition, feed moisture and screw speed) can be seen in Plates 1-15. The effect of the independent variables on the expansion ratio of extrudates is evident. The results shown in the photographs describe the changes that occurred during extrusion as influenced by the extrusion variables.

\section{Conclusion}

A three-factor three level central composite retortable design (CCRD) was adopted to study the effect of extrusion variables level of soybean flour (\%), feed moisture (\%) and screw speed (rpm) on the system parameters; average residence time (s), mass flow rate $\left(\mathrm{gs}^{-1}\right)$, specific mechanical energy $\left(\mathrm{KjKg}^{-1}\right)$, and extrudate properties; expansion ratio and bulk density $\left(\mathrm{gcm}^{-3}\right)$ during the extrusion cooking of pearl-millet and soybean blends for fura production. Results indicated that the variables were significant on target parameters. There were obvious correlations between system parameters and product properties. Therefore, 
target properties of extrudate could be controlled and monitored by regulating the process parameters and the system parameters respectively. The importance of process variables on system parameters and physical properties could be ranked in the following order: Feed Moisture $\left(\mathrm{X}_{2}\right)>$ Feed Composition $\left(\mathrm{X}_{1}\right)>$ Screw Speed $\left(\mathrm{X}_{3}\right)$. Response variables predicted with model equations under optimum conditions were in general agreement with experimental data. The CCRD was effective in optimizing the process condition for fura as influenced by feed composition, feed moisture and screw speed. Sensory scores (result not shown) indicated that the products were accepted by panelist that are used to the product. This could enhance the wide usage of the process conditions by interested processors. Therefore the model could be used to navigate the design space to produce products of desired product characteristics. Extrusion cooking of fura constituted a great improvement on the traditional product that is at high moisture content of between $60-75 \%$ and readily deteriorates on storage. Extrudates obtained in this study had moisture content less than $7 \mathrm{~g} / 100 \mathrm{~g}$ (results not shown) and would not require refigeration for storage.

\section{Acknowledgement}

The funding and support provided by INTERNATIONAL FOUNDATION FOR SCIENCE (IFS) is gratefully acknowledged and appreciated.

\section{References}

Akdogan, H. (1996). Pressure, torque, and energy responses of a twin screw extruder at high moisture contents. Food Research International, 29(5-6), 423-429.

Altan, A. McCarthy, K. L., \& Maskan M. (2008). Evaluation of snack foods from barley-tomato pomace blends by extrusion processing. Journal of Food Engineering, 84, 231-242. http://dx.doi.org/10.1016/j.jfoodeng.2007.05.014s

Altan, A. McCarthy, K. L., \& Maskan M. (2009). Effect of screw configuration and raw material on some properties of barley extrudates. Journal of Food Engineering, 92, 377-382. http://dx.doi.org/10.1016/j.jfoodeng.2008.12.010

Alvarez-Martinez, L., Kondury, K. P., \& Harper, J. M. (1988). A general model for expansion of extruded products. Journal of Food Engineering, 53, 609-615.

Antila, J., Eiler, K., \& Linko, P. (1983). Production of flat bread by extrusion cooking using different wheat/rye ratios, protein enrichment and grain with poor baking ability. Journal of Food Engineering, 2, 189-210. http://dx.doi.org/10.1016/0260-8774(83)90010-9

Baik, B. K., Powers, J., \& Nguyen, L. T. (2004). Extrusion of regular and waxy barley flours for production of expanded cereals. Cereal Chemistry, 81, 94-99. http://dx.doi.org/10.1094/CCHEM.2004.81.1.94

Bhattacharya, M., \& Hanna, M.A. (1987). Influence of process and product variables and extrusion energy and pressure requirements. Journal of Food Engineering, 6, 153-163. http://dx.doi.org/10.1016/0260-8774(87)90037-9

Bhattacharya, M., \& Hanna, M.A. (1988). Effect of Lipids on the properties of extruded 
$\begin{array}{lllll}\text { products. Journal of Food } & \text { Science, } & 53,766 .\end{array}$ http://dx.doi.org/10.1111/j.1365-2621.1988.tb13572.x

Binoy, K. G., Aaron, J. O., \& Gour, S. C. (1996). Reverse screw Element(s) and Feed Composition effects during Twin-Screw Extrusion of ice Flour and Fish Muscle Blends. Journal Food Science, 61(3) 590-595. http://dx.doi.org/10.1111/j.1365-2621.1996.tb13165.x

Boonyasirikool, P., Charunuch, \& Phongpipatpong, M. (1996). Production ofbean snack by twin-extruder. Food in Thailand, 26(1), 14-33.

Brummer, T., Meuser, F., van Lengerich, B., \& Niemann, C. (2002). Effect of extrusion cooking on molecular parameters of corn starch. Starch/Starke, 54, 1-8. http://dx.doi.org/10.1002/1521-379X(200201)54:1<1::AID-STAR1>3.0.CO;2-9

Chessari, C. J., \& Sallahewa, J. N. (2001). Effective Process Control. In: Extrusion Cooking: Technologies and Applications. (Ed. R. Guy). Pp 83-107. Woodhead Publishing Co., Cambridge, England. http://dx.doi.org/10.1533/9781855736313.1.83

Chinnaswamy, R., \& Hanna, M. A. (1990). Relationship between viscosity and expansion properties of various extrusion-cooked grain components. Food Hydrocolloids, 3, 423-434. http://dx.doi.org/10.1016/S0268-005X(09)80220-8

Chiyakul, S., Jangchud, K., Janchud, A., Wuttijumnong, P., \& Winger, R. (2009). Effect of extrusion conditions on physical and chemical properties of high protein glutinous rice-based snack. LWT Food Science and Technology, 42, 781-787. http://dx.doi.org/10.1016/j.lwt.2008.09.011

Choudhury, G.S., \& Gautam, A. (2003). Effects of hydrolysed fish muscle on intermediate process variables during twin-screw extrusion of rice flour. Lebensmittel -und- technologie, 36, 667-678.

Chuang, G. C., \& Yeh, A. (2004). Effect of screw profile on residence time distribution and starch gelatinization of rice flour during single screw extrusion cooking. Journal of Food Engineering, 63, 21-31. http://dx.doi.org/10.1016/S0260-8774(03)00278-4

Company, New York. http://dx.doi.org/10.1007/978-1-4684-1464-6

Conway, H. F. (1971). Extrusion cooking of cereals and soybeans. I. Food Product Development, 5, 2729 - 31.

Della Valle, G., KKozlowski, Colonaa, P., \& Tayeb, J. (1989). Starch transformation estimated by energy balance on a twin screw extruder. Lebensm. Wiss. u. Technol., 22 279-286.

Ding, Q. B., Ainsworth, P., Plunkett, A., Tucker, G., \& Marson, H. (2006). The effect of extrusion conditions on the functional and physical properties of wheat-based expanded

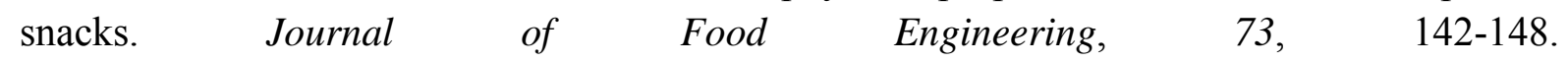
http://dx.doi.org/10.1016/j.jfoodeng.2005.01.013 
Dogan, H., \& Karwe, M. V. (2003). Physicochemical properties of quinoa extrudates. Food Science and Technology International, 9(2), 101-114. http://dx.doi.org/10.1177/1082013203009002006s

E. de Mesa, N. J., Alavi, S., Singh, N., Shi, Y., Dogan, H., \& Sang, Y. (2009). Soy protein-fortified expanded extrudates: Baseline study using normal corn starch. Journal of Food Engineering, 90, 262-270. http://dx.doi.org/10.1016/j.jfoodeng.2008.06.032

Faubion, J.M., \& Hoseney, R.C. (1982). High temperature short time extrusion cooking of wheat starch and flour. 1: role of moisture and flour type in the production of extrudates. Cereal Chemistry, 59, 533-543.

Filli K. B., \& Nkama I. (2007). Hydration properties of extruded fura from millet and legumes. British Food Journal, 109(1), 68-80. http://dx.doi.org/10.1108/00070700710718516

Gacula (jr) M.C., \& Singh J. (1984). Statistical Methods in Food and Consumer Research, Academic Press, Inc., New 214-272. http://dx.doi.org/10.1016/B978-0-08-091831-0.50012-6

Gogoi, B. K., Wang, S. S., \& Yam, K. L. (1995). Applications of shear induced rate constant model to conversion of corn meal in a twin -screw extruder. Journal of Food Process Preserv., 19, 53-63. http://dx.doi.org/10.1111/j.1745-4549.1995.tb00277.x

Govindasamy, S., Campanella, O.H., \& Oates, C. G. (1997). High moisture twin srew extrusion of sago starch.II. Saccharification as influenced by thermomechanical history. Carbohydrates polymers, 32, $267-274$.

Gujral, H. S., Singh, N., \& Singh, B. (2001). Extrusion behaviour of grits from flint and sweet corn. Food Chemistry, 74, 303-308. http://dx.doi.org/10.1016/S0308-8146(01)00156-X

Hagenimana, A., Ding, X., \& Fang, T. (2006). Evaluation of rice flour modified by extrusion cooking. (2006). Journal of Cereal Science, 43, 38-46. http://dx.doi.org/10.1016/j.jcs.2005.09.003

Harmann, D. V., \& Harper, J. M. (1973). Effect of extruder geometry on torque and flow. American Society of Agricultural Engineering, 16, 1175-1178. http://dx.doi.org/10.13031/2013.37727

Harper, J. M., \& Tribelhorn, R. E. (1992). Expansion of native cereal starch extrudates. In J. L. Kokini, C. T. Ho, and M. V. Karwe, Food Extrusion Science and Technology (pp. 653-667). New York : Marcel Dekker.

Ilo, S., Liu, Y., \& Berghofer, E. (1999). Extrusion cooking of rice flour and amaranth blends. Lebensmittel-Wissenschaft und Technologie, 32, 79-88.

Ilo, S., Tomschik, U., Berghofer, E., \& Mundigler, N. (1996). The effect of extrusion operating conditions on the apparent viscosity and the properties of Wissenschaft und-Technologie, 29, 593-598. http://dx.doi.org/10.1006/fstl.1998.0497

Janes, D. A. (1993). Methods for assessing raw materials and extrudates. Ingrediendts Extra, 
12/93 9-34.

Jideani, V. A., Nkama, I., Agbo E. B., \& Jideani I. A. (2002). Identification of the hazard and critical control (HACCP) in traditional fura manufacture. Nigerian Food Journal, 19 42-48.

Kang, L. N., Wei, Y. M., \& Zhang, B. (2007a). Effects of processing parameters on specific on mechanical energy in soy protein texturization by high moisture extrusion. Journal of the Chinese Cereals and Oil Association, 22(3), 38-42.

Kang, L. N., Wei, Y. M., \& Zhang, B. (2007b). Effects of technological parameters on system pressure and torque in soy protein texturization by high moisture extrusion. Journal of the Chinese Cereals and Oil Association, 22(4), 43-49.

Kokini, J.L., Chang, C. N., \& Lai, L. S. (1991). The role of rheological properties on extrudate expansion. In Food Extrusion Science and Technology, J.K kokini, C-T Ho, and M. V. Karwe (Eds), Pp. 345-360. Marcel Dekker, New York.

Kumar, A., Ganjyal, G. M., Jones, D. D., \& Hanna, M. A. (2008). Modeling residence time distribution in a twin-screw extruder as a series of ideal steady-state flow reactors, Journal of Food Engineering, 84, 441-448. http://dx.doi.org/10.1016/j.jfoodeng.2007.06.017

Launary, B., \& Lisch, J. M. (1983). Twin-screw extrusion cooking of starches: flow behaviour of starch pastes, expansion and mechanical properties of extrudates. Journal of Food Engineering, 2, 259-280. http://dx.doi.org/10.1016/0260-8774(83)90015-8

Lewis M. J. (1987). Physical Properties of Food and Food Processing Systems. ELLIS Harwood international publisher in Science and technology England.

Liang Chen, F., Wei, Y., Zhang, B., \& Ojokoh (2008). System parameters and product properties response protein extruded at wide moisture. Journal of Food Engineering, 96, 208-213.

Likimani, T.A., Sofos, J.N., Maga J.A., \& Harper, J.M. (1991). Extrusion cooking of corn/soybeanmix is presence of thermostable a-amylase. Journal of Food Science, 56(1) 99-105. http://dx.doi.org/10.1111/j.1365-2621.1991.tb07985.x

Mange, C. and Boissonant, P. (1987). Distribution of residence time and comparison of three twin screw extrusion of different size. Extrusion Technology for the Food Industry, (Ed) C. O'Connor. Elsevier Applied Science, London, Pp. 117-131.

Martelli, F. G. (1983). Twin Screw Extuders: A Basic understanding. Van Nostrand Rheinhold Meng, X., Threinen, D., Hansen, M., \& Driedger, D. (2010). Effects of extrusion conditions on system parameters and physical properties of a chickpea flour-based snack. Food Research International, 43, 650-658. http://dx.doi.org/10.1016/j.foodres.2009.07.016

Meuser, C., \& van Lengerich, B. (1992). System analytical model for the extrusion of starches. In J. L. Kokini, C. Ho, and M. V. Larwe (Eds.), Food Extrusion Science and Technology. (pp 619-630). New York: Marcel Dekker Inc. 
Meuser, F. and Van Lengerich, B. (1984a). System analytical model for the extrusion for the extrusion of starches. In: Thermal Processing and Quality Control of Foods, eds P. Zeuthen, J. C. Cheftel, C. Eriksson, M. Jul, H. Leniger, P. Linko, Varela \& G. Vos, Elsevier Applied Science, London. Pp. 175-179.

Meuser, F. and van Lengerich, B. (1984b). System analytical model for the extrusion for the extrusion of starches. In: Thermal Processing and Quality Control of Foods, eds P. Zeuthen, J. C. Cheftel, C. Eriksson, M. Jul, H. Leniger, P. Linko, Varela \& G. Vos, Elsevier Applied Science, LondonPp. 180-184.

Meuser, F., van Lengerich, B., Pfaller, W., \& Harmuth-Hoene, A. E. (1985). The influence of HTST extrusion cooking on the protein nutritive value of cereal based products, AACC $70^{\text {th }}$ Annual Meeting, Orlando, Florida.

Meuser, F., Pfaller, W., \& van Lengerichi, B.(1987). Technological aspects regarding specific changes to the characteristic properties of extrudates by HTST extrusion cooking. In Extrusion Technology for the Food Industry, (Ed) C. O'Connor. Elsevier Applied Science, London, Pp. 35-53.

Mohammed, S. (1990). Factors affecting extrusion characteristic of expanded starch-based product. Journal of Food Processing and Preservation, 14, 437-452. http://dx.doi.org/10.1111/j.1745-4549.1990.tb00145.x

Montgomery, D.C. (1984). Design and Analysis of Experiments, $2^{\text {nd }}$ ed.John Wiley and Sons, New York, NY.

Moraru, C. I., \& Kokini, J. L. (2003). Nucleation and expansion during extrusion and microwave heating of cereal foods. Comprehensive Reviews in Food Science and Food Safety, 2, 120-138. http://dx.doi.org/10.1111/j.1541-4337.2003.tb00020.x

Neelam S., Kumbhar B.K., \& Manoj K. (2006). Modeling of Extrusion process using response surface methodology and artificial neural networks. Journal of Engineering Science and Technology, 1(1), 31-34.

Nkama, I., \& Filli, K. B. (2006). Development and Characteristics of Extruded fura from mixtures of pearl millet and grain legumes flours. International journal of food properties, 9,157-165. http://dx.doi.org/10.1080/10942910600596605s

Oyango, C. (2005). Process Optimisation for the production of High Energy Density Fermented or Acidified and Extruded Uji. Dissertation submitted for the award of Doctor Ingenieur (Dr.-Ing.). Fakultat Maschinenwesen Institut for Lebensmithtel und Bioverfahrenstechhnik Technische Universitat Dresden, Dresden, Germany.

Panmanbhan, M., \& Bhattacharya, M. (1989). Extrudate expansion during extrusion cooking of foods. Cereal Food World, 34, 245-249.

Pansawatt, N., Jangchud, K., Jangchud, A., Wuttijumnong, P., Saalia, F. K., Eitenmiller, R. R. \& Philips, R. D. (2008). Effects of extrusion conditions on secondary extrusion variables and physical properties of fish, rice-based snacks. Lebensm-Wiss. U.-Technol., 41, 632-641. 
http://dx.doi.org/10.1016/j.lwt.2007.05.010

Pham, C. B., \& Del Rosario, R. R. (1984). Studies on the development of texturised vegetables products by the extrusion process. Journal of Food Technology, 19, 549-559.

Qing-Bo, D., Ainsworth, P., Tuker, G., \& Marson, H. (2005). The effect of extrusion conditions on the physicochemical properties and sensory characteristics of rice-based expanded snacks. Journal of Food Engineering, 66, 284 -289.

Sandra, H. P., \& Areas, J. A. G. (1993). Protein-Protein Interactions in the Extrusion of Soya at Various Temperatures and Moisture Contents. Journal Food Science, 58(2), 378-381. http://dx.doi.org/10.1111/j.1365-2621.1993.tb04279.x

Seker, M. (2005). Selected properties of native starch or modified maize starch/soy protein mixtures extruded at varying screw speed. Journal of the Science of Food and Agriculture, 85(7), 1161-1165. http://dx.doi.org/10.1002/jsfa.2086

Senouci, A., \& Smith, A. C. (1986). The extrusion cooking of potato starch material. Starch/Strake, 38, 78-82. http://dx.doi.org/10.1002/star.19860380304

Singh, B., Sekhon, K. S., \& Singh, N. (2007). Effects of moisture, temperature and level of pea grits on extrusion behaviour and product characteristics of rice. Food Chemistry, 100, 198-202. http://dx.doi.org/10.1016/j.foodchem.2005.09.042

Sopade P. A., \& Le Grys G. A. (1991). Effect of added sucrose on extrusion cooking of maize Starch. Food Control, 20, 103-109. http://dx.doi.org/10.1016/0956-7135(91)90146-N

SPSS (1998). Statistical package for the social sciences for windows Illinois, USA: SPSS

Taranto, M. V. Cegla, G.F., Bell, R. K., \& Rhee, K. C. (1978). Morphological, ultrastructural and rheological evaluation of soy and cottonseed flours texturized by extrusion and nonextrusion processing. Journal Food Science, 43, 973. http://dx.doi.org/10.1111/j.1365-2621.1978.tb02465.x

United Soybean Board, (2006). Consumer attitudes about nutrition; insights into nutrition; health and soy foods. $13^{\text {th }}$ Annual National Report. Chesterfield, Mo: USB

Van Zuliichem, D. J., Janger, T., \& Stolp, W. (1988). Residence time distribution in extrusion cooking. Part II: Single screw extruders processing maize and soya. Journal of Food Engineering, 7, 197. http://dx.doi.org/10.1016/0260-8774(88)90003-9

Wanasundara, P. K. J. P. D., \& Shahidi, F. (1996). Optimization of hexametaphosphate-assisted extraction of flaxseed protein using response surface methodology. Journal of Food Science, 61(3), 604-607. http://dx.doi.org/10.1111/j.1365-2621.1996.tb13168.x

Wang, H. W. (2005). Influence of processing variables on system in twin - screw extrusion of soy protein. Journal of the Chinese Oil, 30(9), 28-30.

Wang, H. W., Zhou, J. G., \& Lin, B. J. (2001). Effect of processing variables of twin-screw 


\section{IIMacrothink}

Journal of Food Studies

ISSN 2166-1073 2015, Vol. 4, No. 1

extrusion on texturization of compound soybean protein. Journal of the Chinese Cereals and Oils Association, 16(2), 54-58.

Wang, S.S., Ching, W. C., Zhao, B. L., Zheng, Z. X., \& Kim, I. H. (1991). Experimental analysis and computer simulation of starch-water interaction during phase transition. Journal of Food Science, 56(1), 121- 124.

Yeu, K., Lee. Y., \& Lee., S. Y. (2008). Consumer Acceptance of an Extruded Soy-Based High-Protein Breakfast Cereal. Journal of Food Science, 73(1), S20-S25. http://dx.doi.org/10.1111/j.1750-3841.2007.00601.x

Zasypkin, D .V, \& Tung- Ching L. (1998). Extrusion of Soybean and Wheat Flour as Affected by Moisture content. Journal of Food Science, 63(6), 1058-1061. http://dx.doi.org/10.1111/j.1365-2621.1998.tb15854.x

Table 1. Independent Variables and Levels used for Central Composite Rotatable Design ${ }^{1}$

\begin{tabular}{lllllll}
\hline & & \multicolumn{5}{c}{ Coded variable level $\left(x_{i}\right)$} \\
\cline { 3 - 7 } \multicolumn{1}{c}{ Variable } & Symbol $\left(X_{i}\right)$ & $-1.68(\propto)$ & -1 & 0 & 1 & $1.68(\propto)$ \\
\hline Feed composition (\%) & $\mathrm{X}_{1}$ & 3.2 & 10 & 20 & 30 & 36.8 \\
Feed moisture (\%) & $\mathrm{X}_{2}$ & 16.6 & 20 & 25 & 30 & 33.4 \\
Screw speed (Rpm) & $\mathrm{X}_{3}$ & 116 & 150 & 200 & 250 & 284 \\
\hline
\end{tabular}

${ }^{1}$ Transformation of coded variable $\left(x_{\mathrm{i}}\right)$ levels to uncoded variables $\left(\mathrm{X}_{\mathrm{i}}\right)$ levels could be obtained from $\mathrm{X}_{1}=10 x_{1}+$ $20 ; X_{2}=5 x_{2}+25 ; X_{3}=50 x_{3}+200$ 
Table 2. Experimental design extrusion experiment in their coded form and natural units ${ }^{1,2}$

\begin{tabular}{|c|c|c|c|c|c|c|}
\hline \multirow{2}{*}{\multicolumn{3}{|c|}{$\begin{array}{l}\text { Independent variables in coded form } \\
\text { Design point }\left(X_{1}\right)\left(X_{2}\right)\left(X_{3}\right)\left(X_{1}\right)\left(X_{2}\right)\end{array}$}} & \multicolumn{4}{|c|}{ Experimental variables in their actual values } \\
\hline & & & & & & $\left(\mathrm{X}_{3}\right)$ \\
\hline 1 & -1 & -1 & -1 & 10 & 20 & 150 \\
\hline 2 & -1 & +1 & -1 & 10 & 30 & 150 \\
\hline 3 & -1 & -1 & +1 & 10 & 20 & 250 \\
\hline 4 & -1 & +1 & +1 & 10 & 30 & 250 \\
\hline 5 & +1 & -1 & -1 & 30 & 20 & 150 \\
\hline 6 & +1 & +1 & -1 & 30 & 30 & 150 \\
\hline 7 & +1 & -1 & +1 & 30 & 20 & 250 \\
\hline 8 & +1 & +1 & +1 & 30 & 30 & 250 \\
\hline 9 & -1.68 & 0 & 0 & 3.2 & 25 & 200 \\
\hline 10 & +1.68 & 0 & 0 & 36.8 & 25 & 200 \\
\hline 11 & 0 & -1.68 & 0 & 20 & 16.6 & 200 \\
\hline 12 & 0 & +1.68 & 0 & 20 & 33.4 & 200 \\
\hline 13 & 0 & 0 & -1.68 & 20 & 25 & 116 \\
\hline 14 & 0 & 0 & +1.68 & 20 & 25 & 284 \\
\hline 15 & 0 & 0 & 0 & 20 & 25 & 200 \\
\hline
\end{tabular}

${ }^{1}$ Duplicate tests at all design point except the centre point $(0,0,0)$ which was carried out five times and the result averaged. ${ }^{2}$ Experiment was carried out in randomized order; $\left(\mathrm{X}_{1}\right)=$ feed composition $(\%),\left(\mathrm{X}_{2}\right)=$ feed moisture $(\%)$ and $\left(\mathrm{X}_{3}\right)=$ Screw speed $(\mathrm{rpm})$

Table 3. Experimental design and physical properties of the extruded pearl millet-soybean fura

\begin{tabular}{ccccccccc}
\hline \multicolumn{3}{c}{ Independent variables $^{\mathrm{b}}$} & & \multicolumn{5}{c}{ Dependent variables $^{\mathrm{a}}$} \\
\cline { 1 - 5 } \cline { 5 - 8 } $\mathrm{X}_{1}$ & $\mathrm{X}_{2}$ & $\mathrm{X}_{3}$ & & ART & MFR & SME & ER & BD \\
\hline 10 & 20 & 150 & & $31.01 \pm 0.45$ & $1.34 \pm 0.14$ & $456.34 \pm 0.23$ & $2.64 \pm 0.23$ & $0.165 \pm 0.016$ \\
10 & 30 & 150 & & $31.02 \pm 0.23$ & $1.37 \pm 0.11$ & $384.44 \pm 0.34$ & $1.52 \pm 0.32$ & $0.402 \pm 0.025$ \\
10 & 20 & 250 & & $31.66 \pm 0.12$ & $1.37 \pm 0.12$ & $373.11 \pm 0.32$ & $2.52 \pm 0.36$ & $0.117 \pm 0.015$ \\
10 & 30 & 250 & & $27.12 \pm 0.34$ & $1.32 \pm 0.14$ & $368.28 \pm 0.35$ & $1.78 \pm 0.12$ & $0.321 \pm 0.026$ \\
30 & 20 & 150 & & $30.03 \pm 0.67$ & $1.14 \pm 0.13$ & $389.48 \pm 0.45$ & $2.36 \pm 0.21$ & $0.164 \pm 0.015$ \\
30 & 30 & 150 & & $30.12 \pm 0.35$ & $1.40 \pm 0.11$ & $481.67 \pm 0.53$ & $1.67 \pm 0.34$ & $0.430 \pm 0.013$ \\
30 & 20 & 250 & & $29.11 \pm 0.48$ & $1.36 \pm 0.12$ & $383.61 \pm 0.46$ & $2.48 \pm 0.25$ & $0.181 \pm 0.024$ \\
30 & 30 & 250 & & $25.16 \pm 0.21$ & $1.47 \pm 0.15$ & $372.86 \pm 0.56$ & $1.40 \pm 0.13$ & $0.363 \pm 0.012$ \\
3.2 & 25 & 200 & & $26.25 \pm 0.76$ & $1.39 \pm 0.14$ & $388.76 \pm 0.78$ & $2.37 \pm 0.17$ & $0.174 \pm 0.022$ \\
36.8 & 25 & 200 & & $25.51 \pm 0.37$ & $1.38 \pm 0.12$ & $380.12 \pm 0.74$ & $1.84 \pm 0.16$ & $0.287 \pm 0.012$ \\
20 & 16.6 & 200 & & $31.52 \pm 0.87$ & $1.06 \pm 0.11$ & $383.16 \pm 0.38$ & $2.45 \pm 0.18$ & $0.190 \pm 0.013$ \\
20 & 33.4 & 200 & & $27.21 \pm 0.17$ & $1.34 \pm 0.16$ & $369.23 \pm 0.32$ & $1.47 \pm 0.15$ & 0.4540 .023 \\
20 & 25 & 116 & & $19.15 \pm 0.28$ & $1.30 \pm 0.13$ & $598.36 \pm 0.76$ & $1.81 \pm 0.13$ & $0.295 \pm 0.022$ \\
20 & 25 & 284 & & $20.25 \pm 0.68$ & $1.45 \pm 0.12$ & $388.98 \pm 0.23$ & $2.03 \pm 0.18$ & $0.245 \pm 0.021$ \\
20 & 25 & 200 & & $20.15 \pm 0.89$ & $1.40 \pm 0.15$ & $419.02 \pm 0.49$ & $1.89 \pm 0.11$ & $0.294 \pm 0.032$ \\
\hline
\end{tabular}


${ }^{\mathrm{b}} \mathrm{X}_{1}=$ Feed composition (\%); $\mathrm{X}_{2}=$ Feed moisture $(\%)$ and $\mathrm{X}_{3}=$ Screw speed (rpm). ART $=$ Average residence time; $\mathrm{SME}=$ Specific mechanical energy $\left(\mathrm{Kj} \mathrm{Kg}^{-1}\right)$; MFR = Mass flow rate $\left(\mathrm{gs}^{-1}\right)$; ER = expansion ratio; $\mathrm{BD}=$ Bulk density $\left(\mathrm{Kgm}^{-3}\right) .{ }^{\mathrm{a}}$ Values are means $\quad \pm$ standard deviation of triplicate determinations.

Table 4. Regression equation coefficients for objective physical properties ${ }^{1,2}$

\begin{tabular}{clllll}
\hline & \multicolumn{5}{c}{ Response $^{3}$} \\
\cline { 2 - 6 } Coefficient & ART & MFR & SME & ER & BD \\
\hline Linear & & & & \\
$\mathrm{Sb}_{0}$ & $0.8345^{*}$ & $0.6982^{*}$ & 0.2522 & -0.2424 & 0.2005 \\
$\mathrm{~b}_{1}$ & 0.2945 & -0.0311 & -0.0420 & $-0.2890^{*}$ & $0.2558^{*}$ \\
$\mathrm{~b}_{2}$ & $0.4039^{*}$ & $0.5450^{*}$ & -0.0254 & $-1.0588^{*}$ & $1.0557^{*}$ \\
$\mathrm{~b}_{3}$ & 0.2912 & $0.3468^{*}$ & $-0.7689^{*}$ & 0.0722 & $-0.2084^{*}$ \\
Quadratic & & & & & \\
$\mathrm{b}_{11}$ & $0.3956^{*}$ & -0.1324 & $-0.3444^{*}$ & 0.2251 & $-0.2652^{*}$ \\
$\mathrm{~b}_{22}$ & $0.7100^{*}$ & $-0.7265^{*}$ & $-0.3985^{*}$ & 0.0845 & 0.0853 \\
$\mathrm{~b}_{33}$ & 0.1175 & -0.1645 & $0.3732^{*}$ & 0.0457 & -0.1139
\end{tabular}

Interaction

\begin{tabular}{clllll}
$\mathrm{b}_{12}$ & 0.2647 & $0.4419 *$ & 0.3666 & 0.0308 & 0.0095 \\
$\mathrm{~b}_{13}$ & 0.3393 & 0.3512 & -0.0354 & -0.0993 & 0.1068 \\
$\mathrm{~b}_{23}$ & 0.1177 & -0.2606 & -0.0831 & -0.0034 & -0.1581 \\
\hline $\mathrm{R}^{2}$ & 0.787 & 0.871 & 0.826 & 0.9150 & 0.9639 \\
Adjusted $\mathrm{R}^{2}$ & 0.595 & 0.755 & 0.670 & 0.8384 & 0.9315 \\
Lack of fit & $*$ & $\mathrm{NS}$ & $*$ & $*$ & $*$ \\
Model & $*$ & $*$ & $*$ & $*$ & $*$ \\
\hline
\end{tabular}

${ }^{1} Y=b_{0}+b_{1} X_{1}+b_{2} X_{2}+b_{3} X_{3}+b_{11} X_{1}^{2}+b_{22} X_{2}^{2}+b_{33} X_{3}^{2}+b_{12} X_{1} X_{2}+b_{13} X_{1} X_{3}+b_{23} X_{2} X_{3}$

$X_{1}=$ Feed Composition, $X_{2}=$ Feed Moisture, $X_{3}=$ Screw Speed ${ }^{2} *$ Significant at $\mathrm{P}<0.05$; NS, not significant ${ }^{3} \mathrm{ART}=$ Average residence time; MFR $=$ Mass flow rate; SME $=$ Specific mechanical energy; $\mathrm{ER}=$ expansion ratio; $\mathrm{BD}=$ Bulk density. 


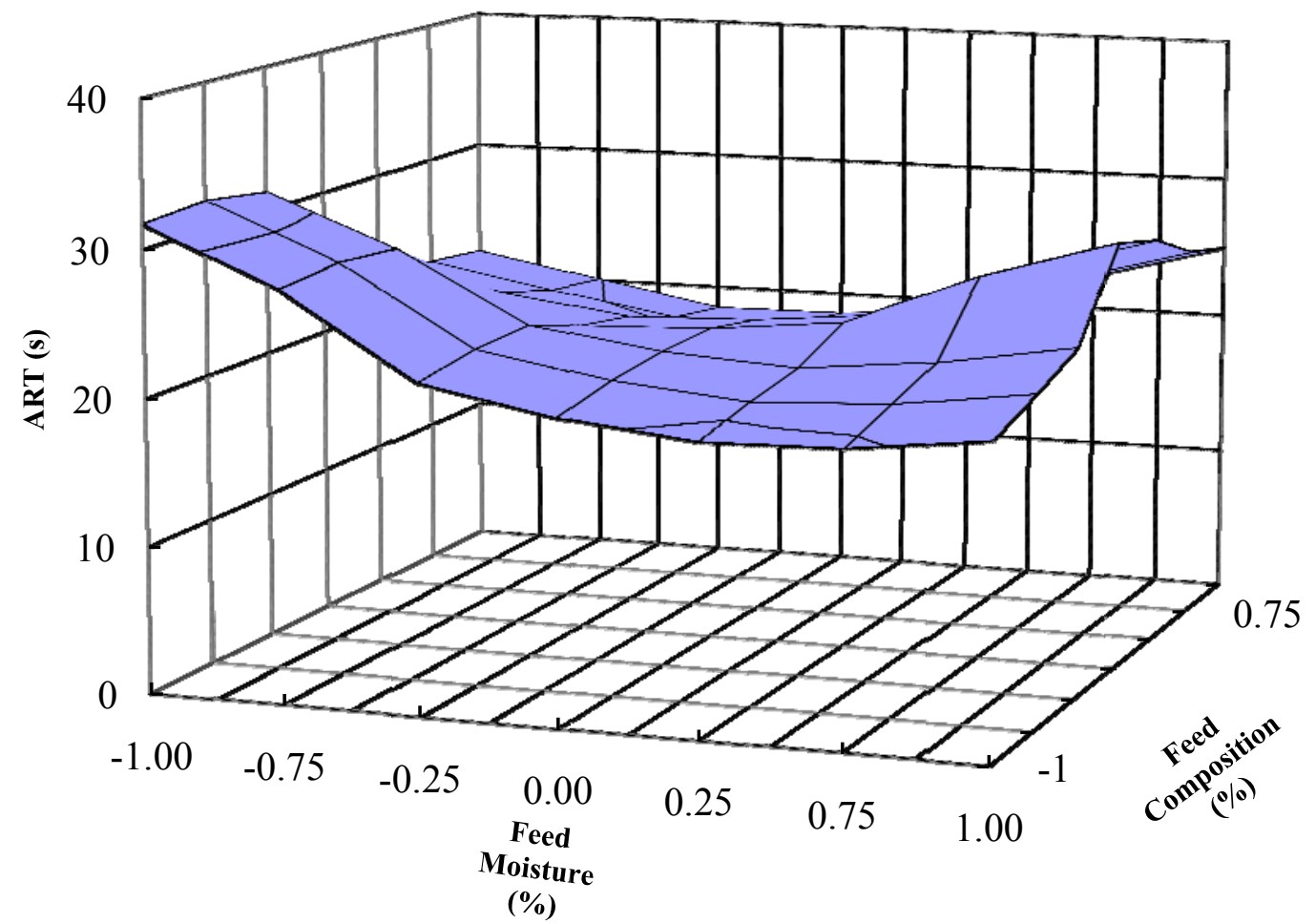

Figure 1. Response effect of feed moisture and feed composition on average residence time (ART) 


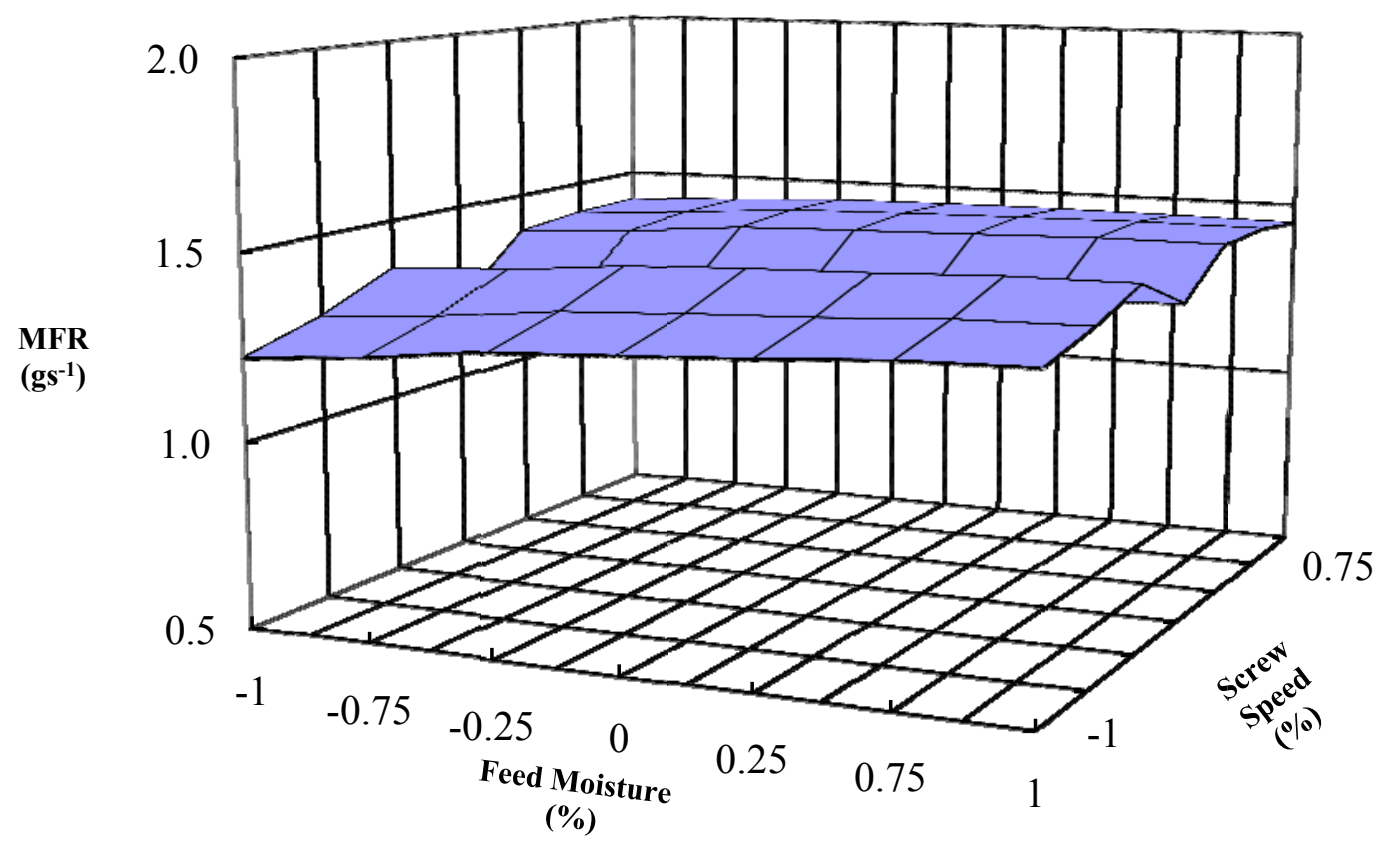

Figure 2. Response effect of feed moisture and screw speed on mass flow rate (MFR) 


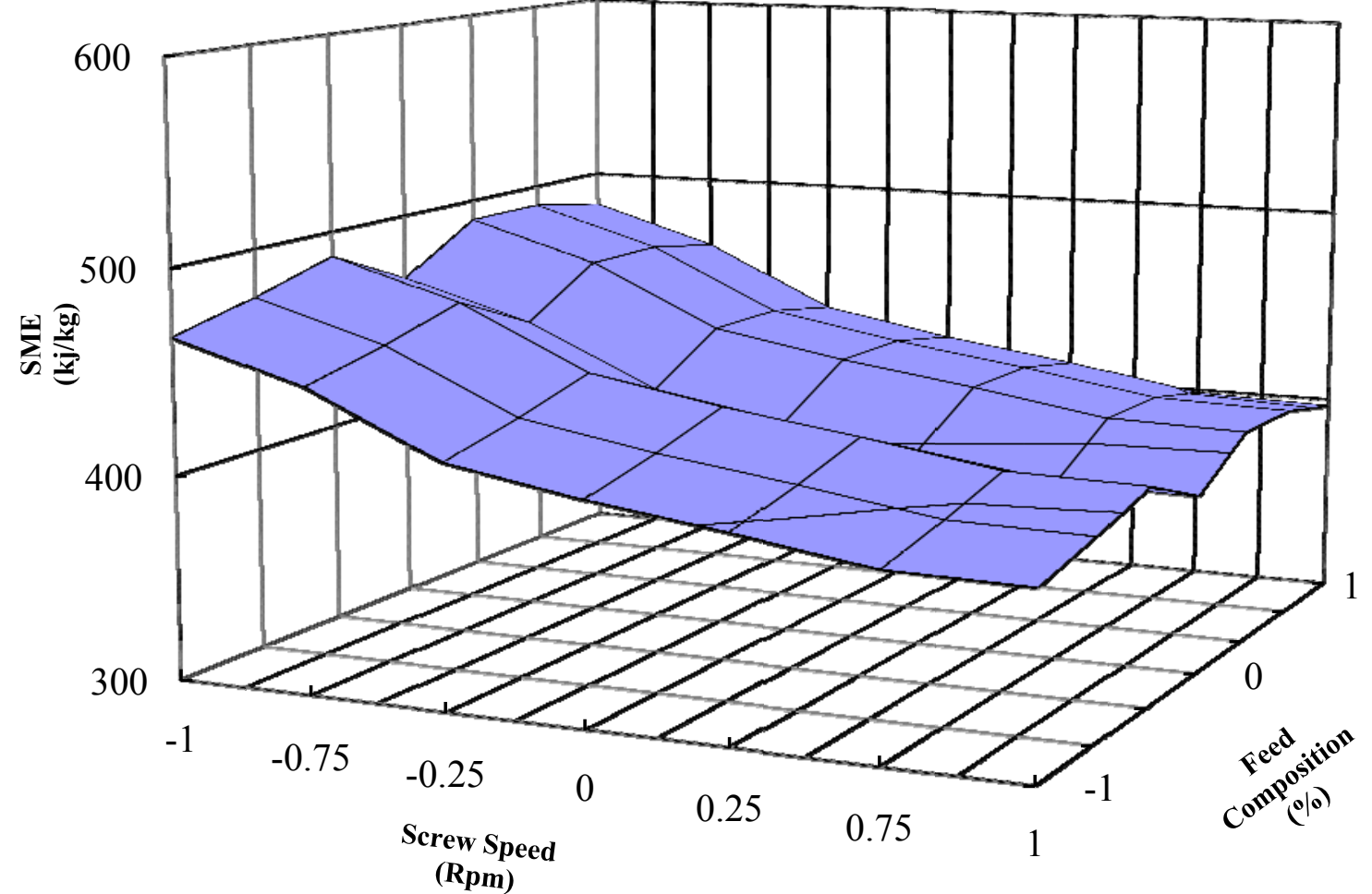

Figure 3. Response effect of screw speed and feed composition on specific mechanical energy (SME) 


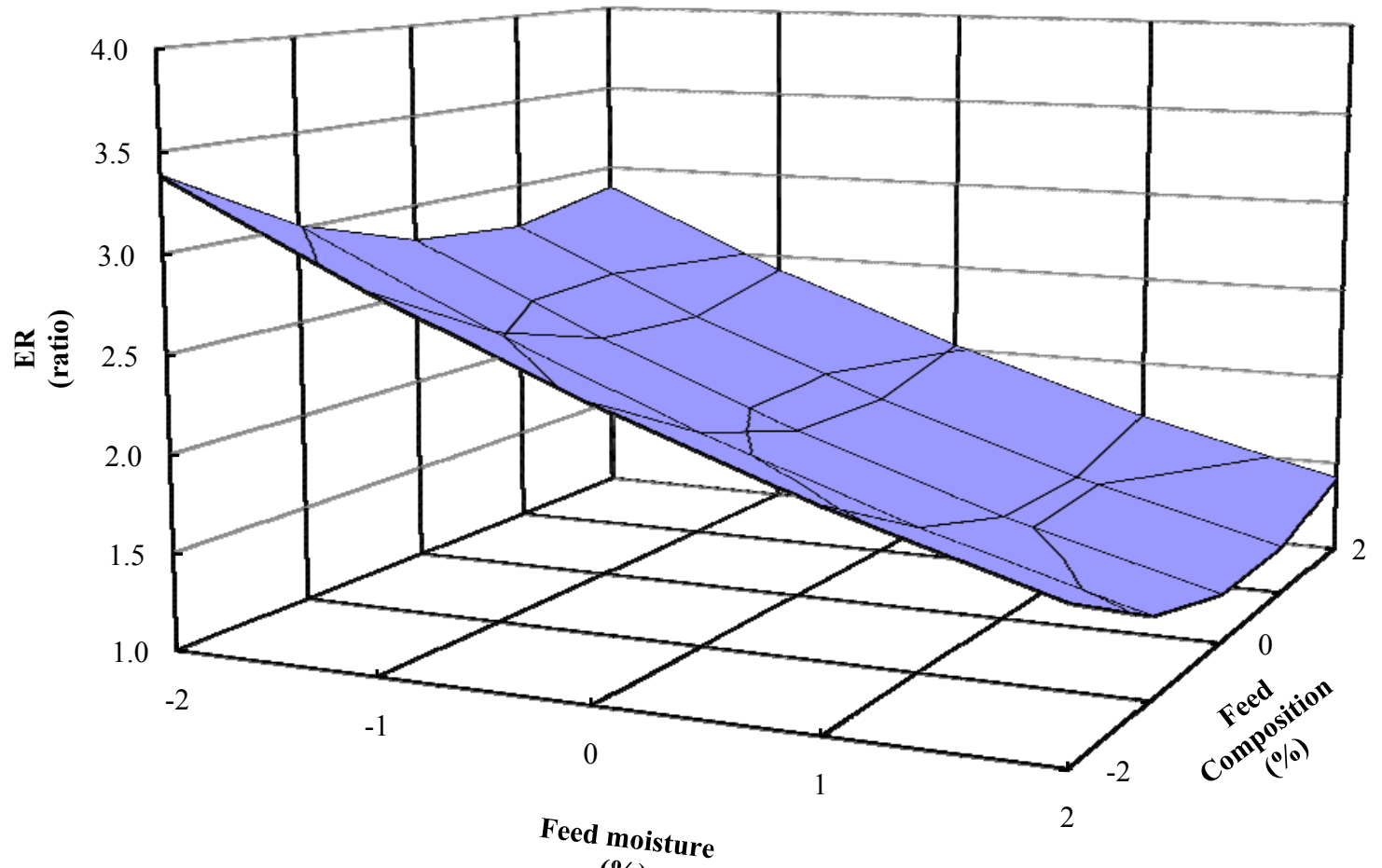

(\%)

Figure 4. Effect of feed moisture and feed composition on expansion ratio (ER) 


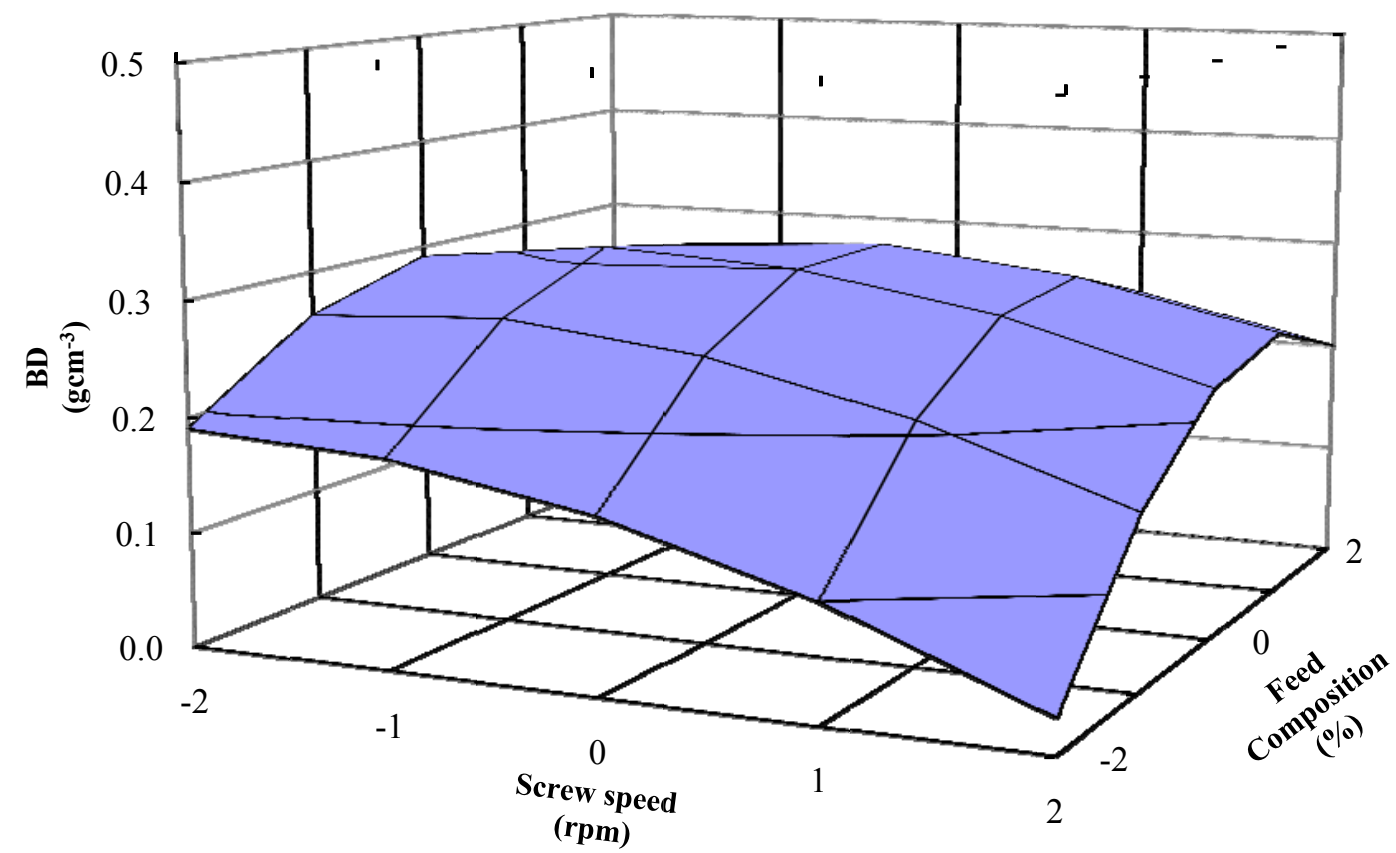

Figure 5. Effect of screw speed and feed composition on bulk density (BD) 


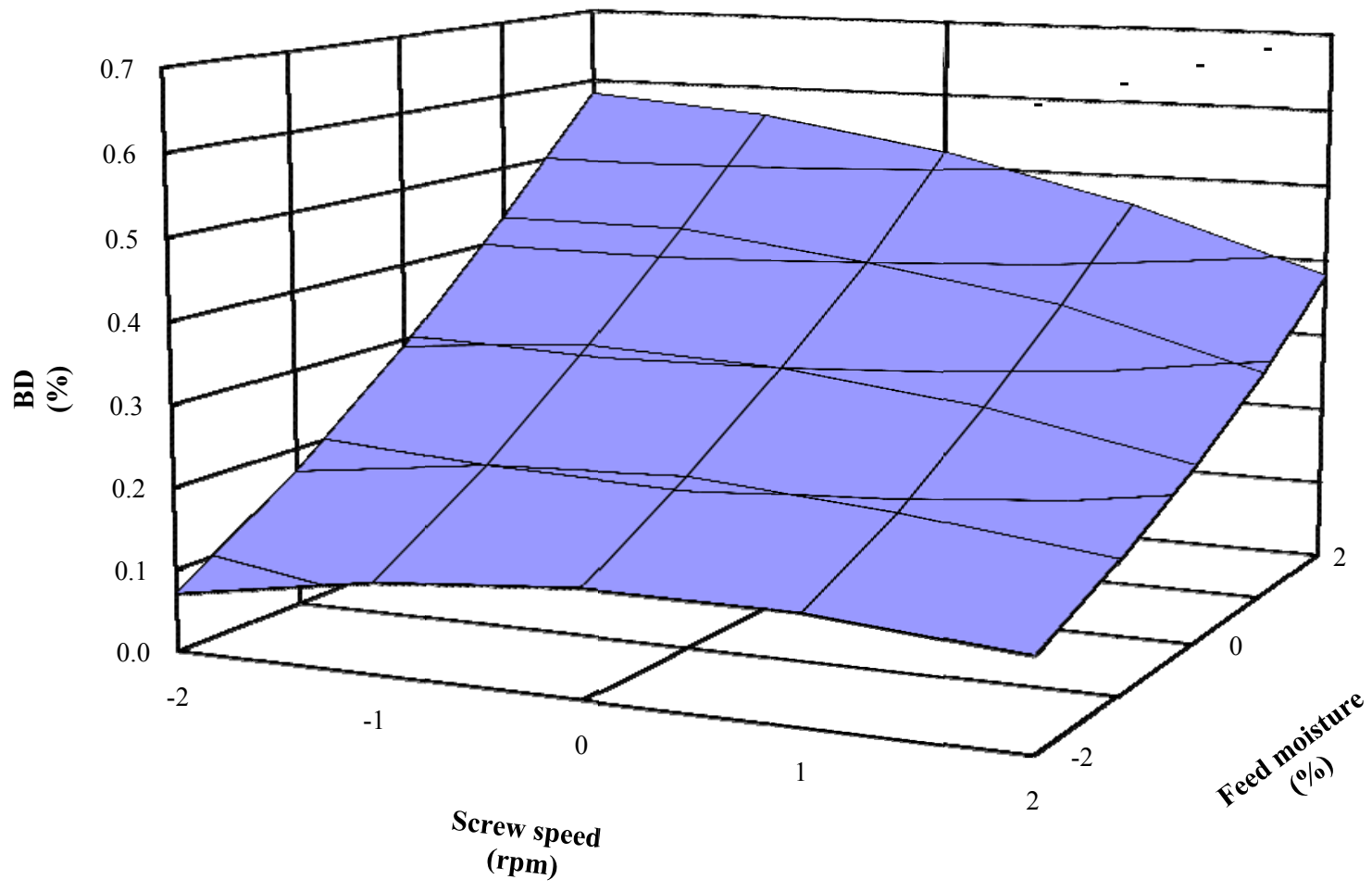

Figure 6. Effect of screw speed and feed moisture on the bulk density (BD) 
$(1)(2)(3)$
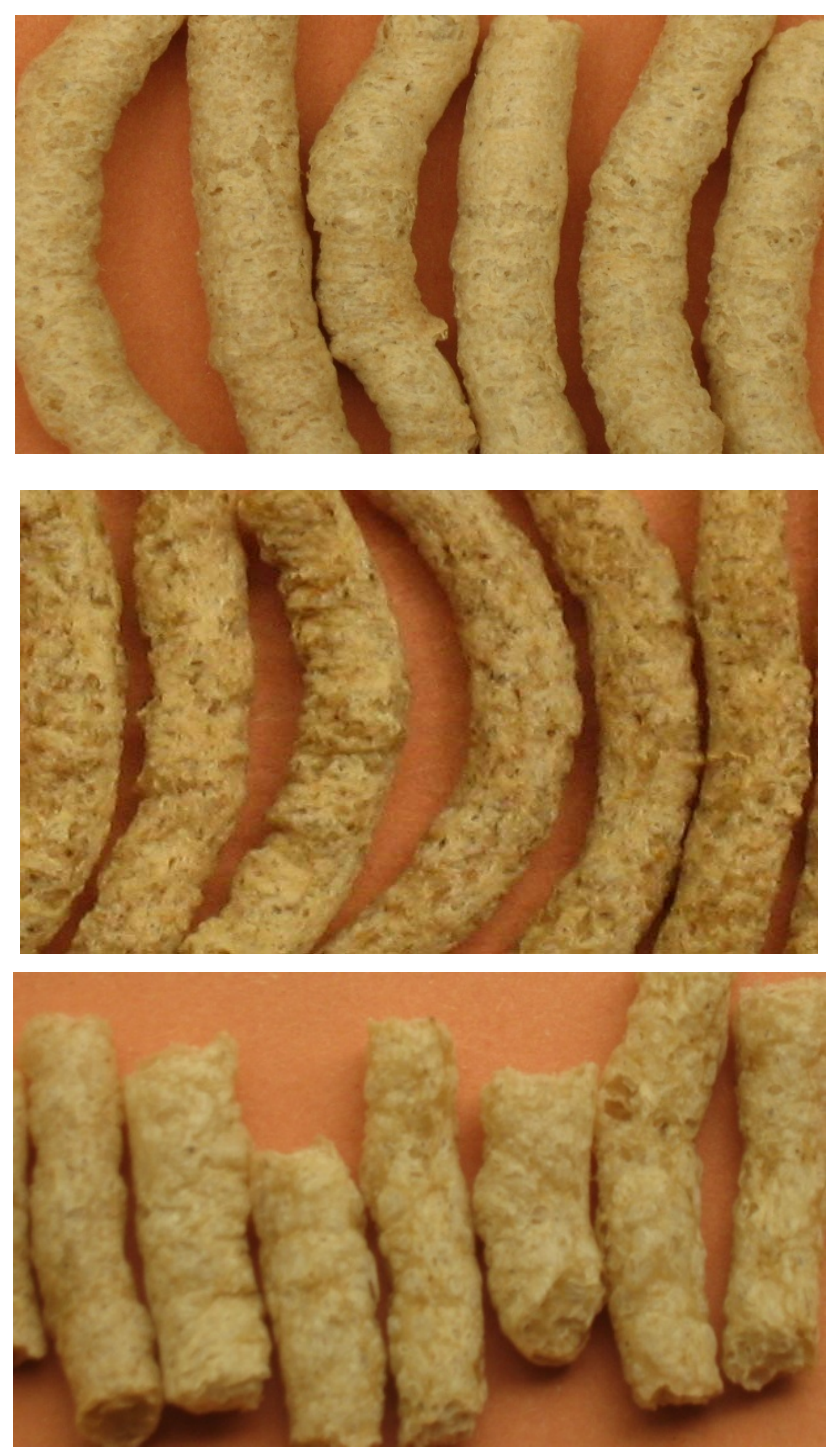
(4) (5) (6)
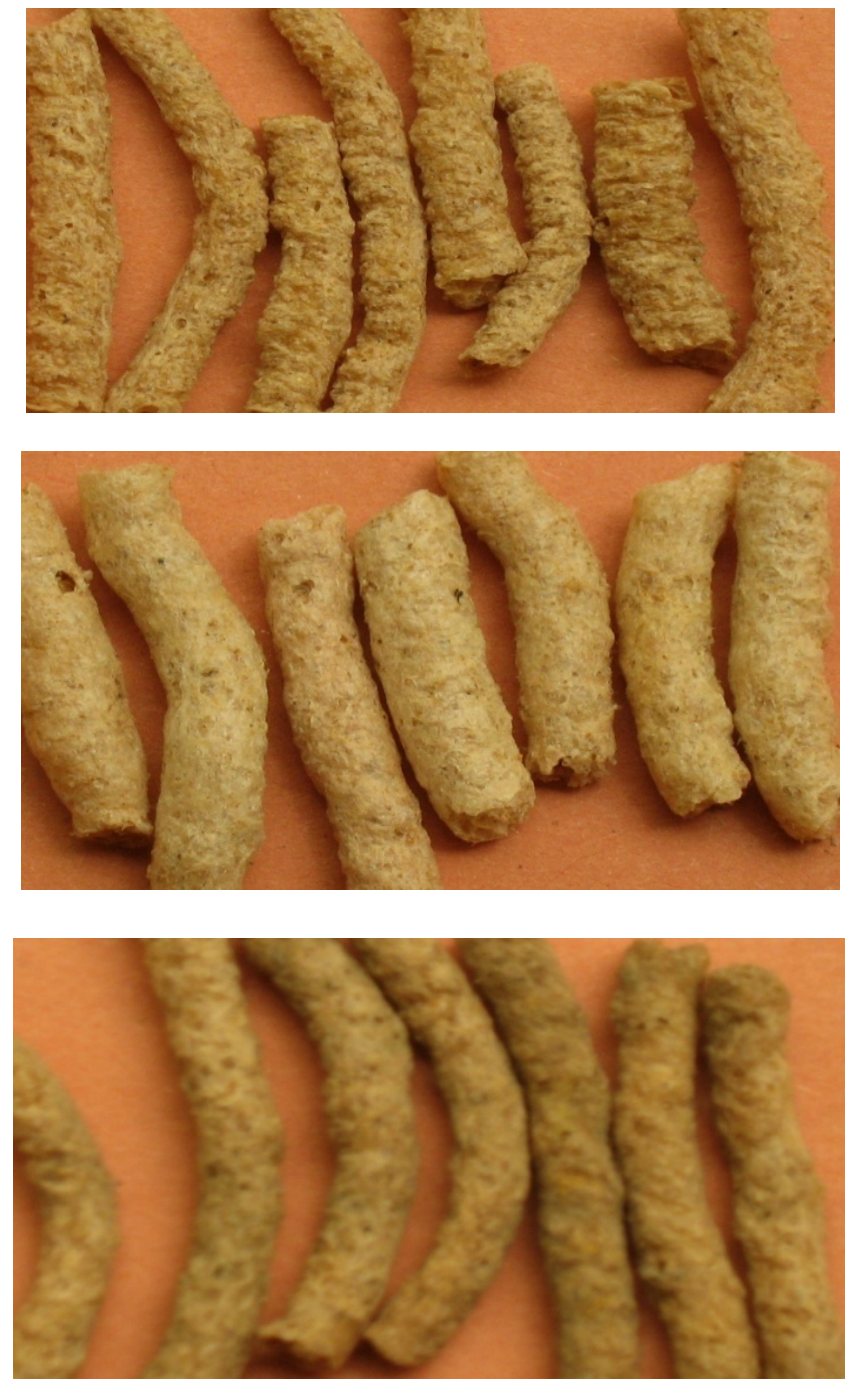


\section{(7)(8) (9)}
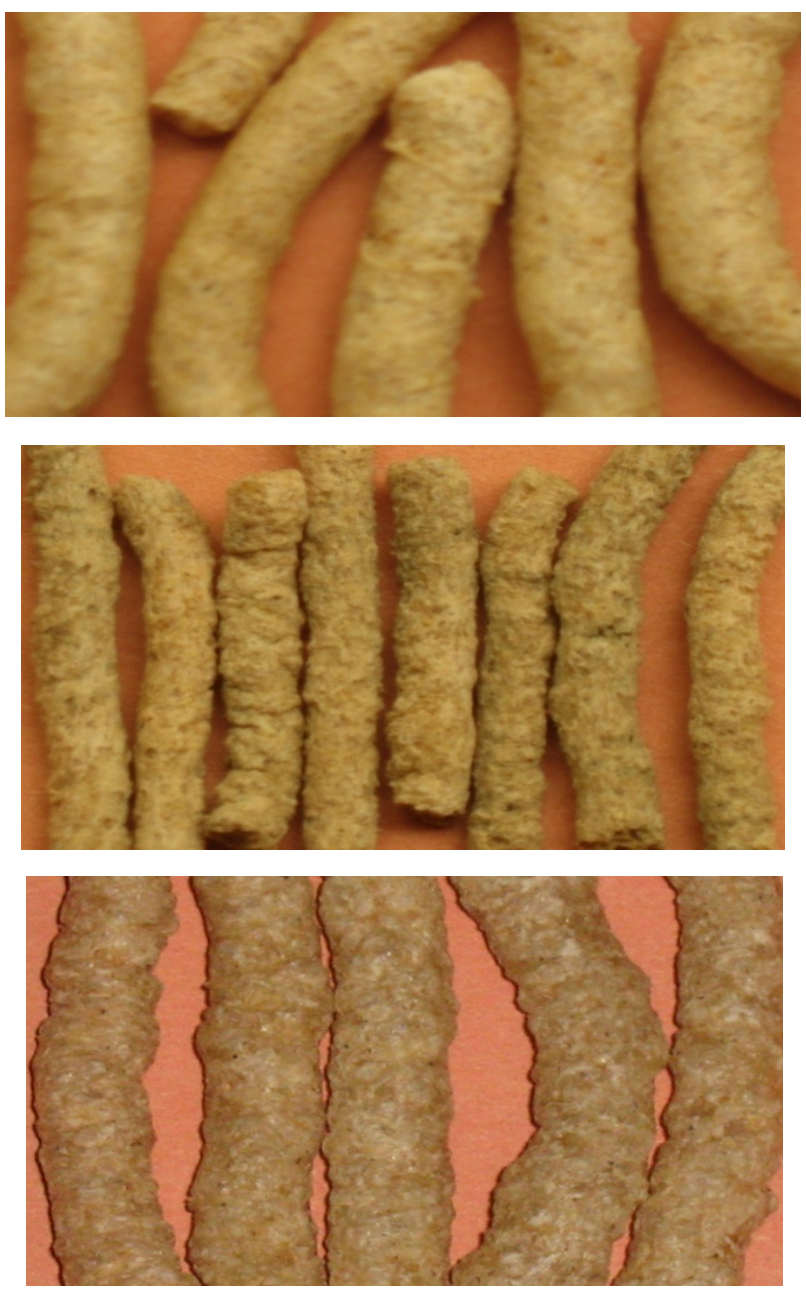

Plates 1-9. Shows the physical state of extrudate responses ; (1) $10 \%$ soybean, $20 \%$ feed moisture, $150 \mathrm{rpm}$ screw speed; (2) 10\% soybean, 30\%moisture,

150rpm screw speed; (3) $10 \%$ soybean, $20 \%$ feed moisture, 250 rpm screw speed; (4) $10 \%$ soybean,30\% feed moisture, 250rpm screw speed; (5) 30\% soybean, 20\% feed moisture, 150rpm screw speed; (6) 30\% soybean, 30\% feed moisture, 150rpm screw speed; (7)30\% soybean, 20\% feed moisture, 250rpm screw speed; (8) 30\% soybean, 30\% feed moisture, 250rpm screw speed; (9) 3.2\% soybean, $25 \%$ feed moisture, $200 \mathrm{rpm}$ screw speed; 


\section{$(10)(11)(12)$}
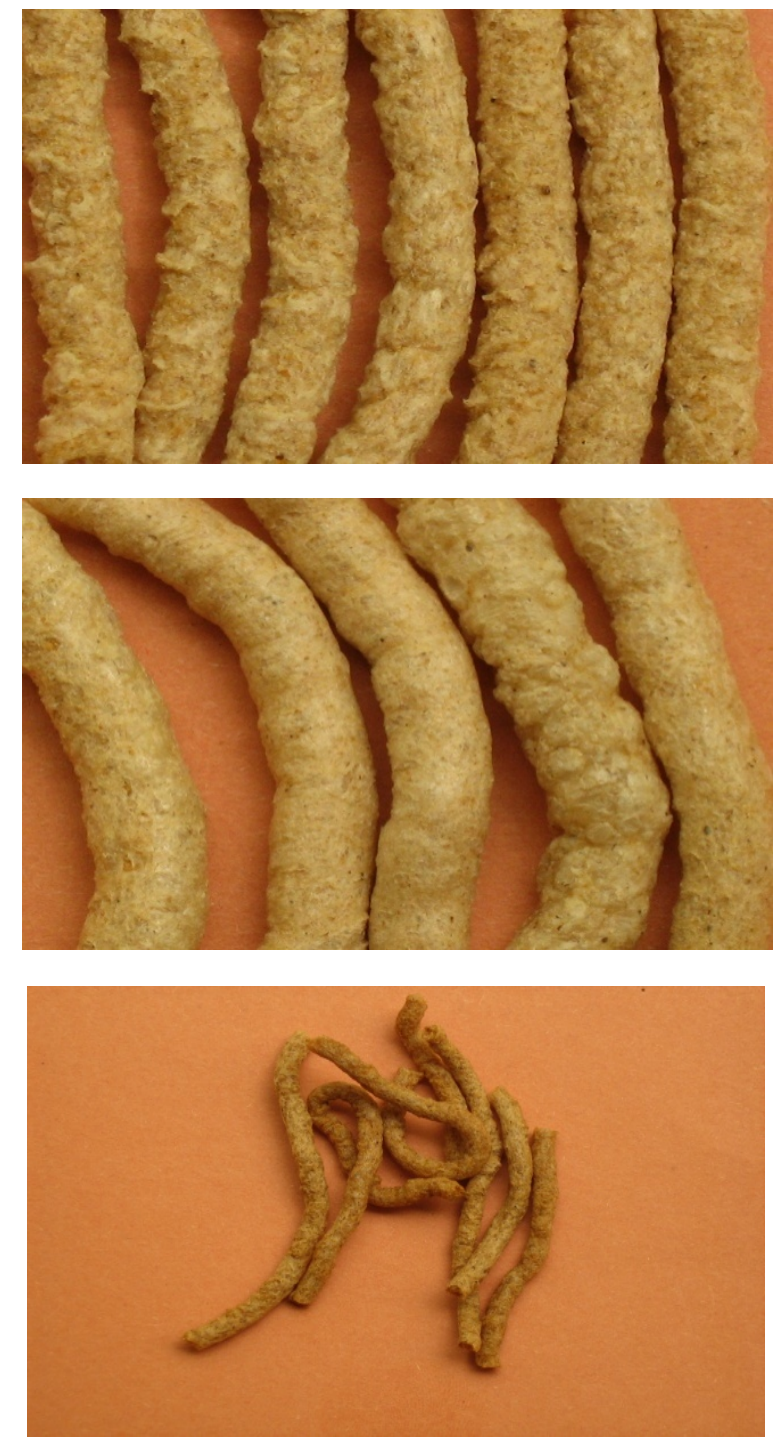


\section{$(13)(14)(15)$}
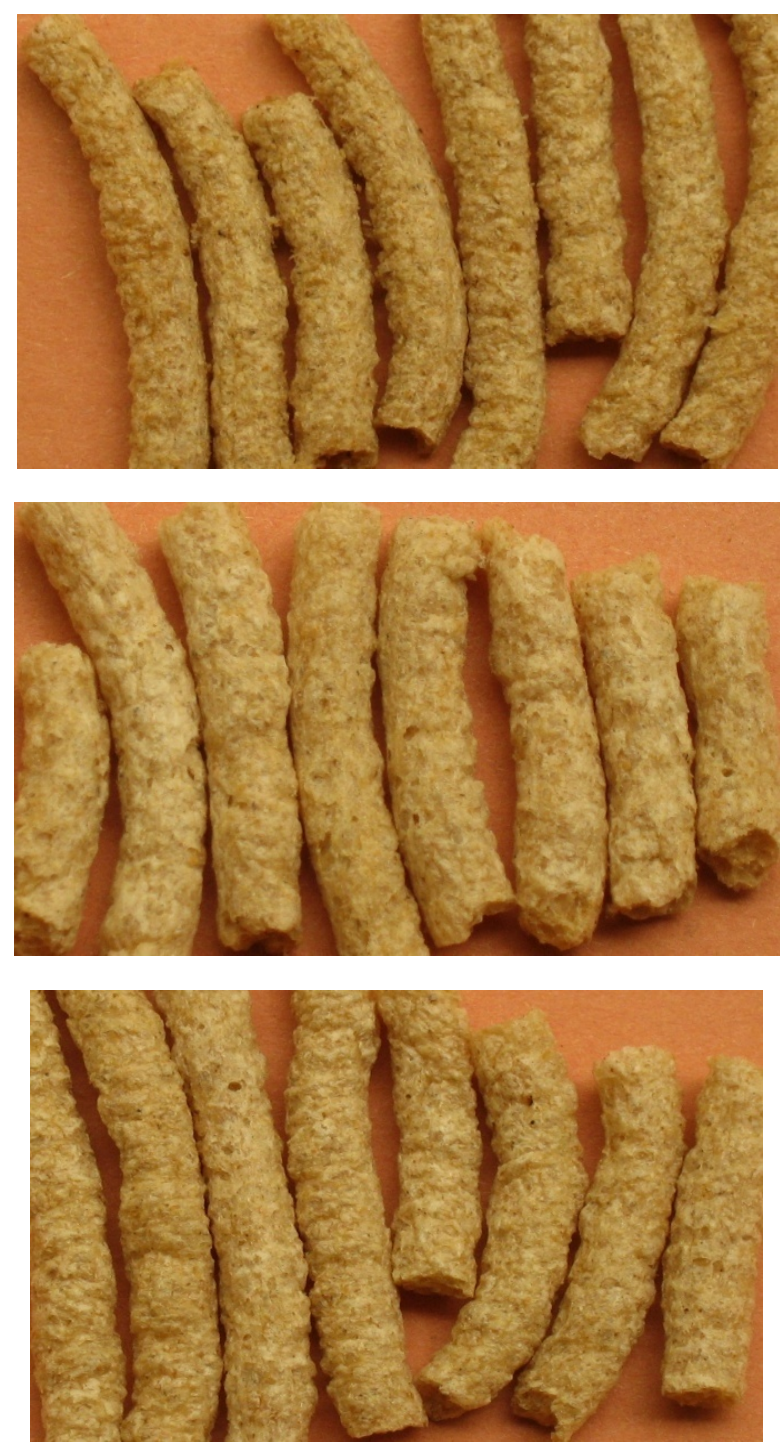

Plates 10-15 Shows the physical state of extrudate responses continues; (10) $36.8 \%$ soybean, $25 \%$ feed moisture, 200rpm screw speed; (11) $20 \%$ soybean, $16.6 \%$ feed moisture, 200rpm screw speed; (12) $20 \%$ soybean, $33.4 \%$ moisture, $200 \mathrm{rpm}$ screw speed; (13) $20 \%$ soybean, $25 \%$ feed moisture, $116 \mathrm{rpm}$ screw speed; (14) $20 \%$ soybean, $25 \%$, feed moisture, $284 \mathrm{rpm}$ screw speed; (15) $20 \%$ soybean, and $25 \%$ feed moisture, $200 \mathrm{rpm}$ screw speed. 